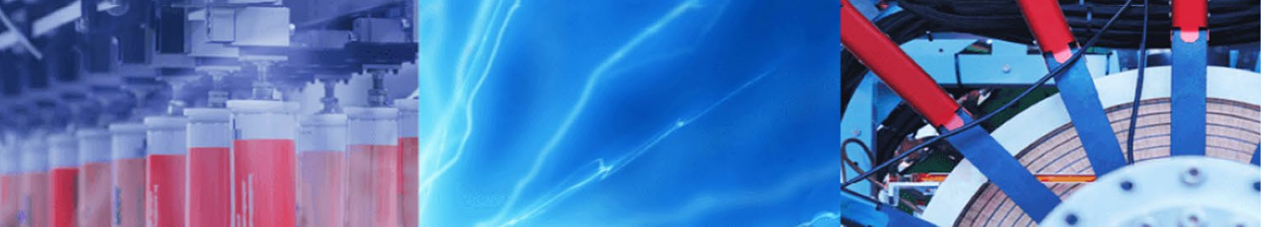

Research Article

\title{
Process optimisation of methylene blue sequestration onto physical and chemical treated coffee husk based adsorbent
}

\author{
T. P. Krishna Murthy ${ }^{1,2,3}$ [D B. S. Gowrishankar ${ }^{3,4}$
}

Received: 6 November 2019 / Accepted: 26 March 2020 / Published online: 7 April 2020

(c) Springer Nature Switzerland AG 2020

\begin{abstract}
Coffee husk $(\mathrm{CH})$ was physically and chemically treated with autoclaving $(\mathrm{SCH})$ and $\mathrm{NaOH}(\mathrm{NCH})$ to develop low-cost adsorbent for the removal of methylene blue (MB) from synthetic wastewater, and their adsorption efficiencies were evaluated in batch mode. The prepared adsorbent was characterised by SEM, FTIR and point of zero charge. The central composite rotatable design (CCRD) was employed to optimise the adsorption process parameters such as $\mathrm{pH}$, adsorbent dosage and initial $\mathrm{MB}$ concentration. The second-order quadratic model fitted best with the experimental adsorption data, and ANOVA results showed that the developed model was significant. The linear terms in the model significantly influence the adsorption capacity of $\mathrm{SCH}$ and $\mathrm{NCH}$, but interaction terms were not significant. At optimised conditions, the developed adsorbents can remove $>90 \%$ of $\mathrm{MB}$ from the aqueous solution. Freundlich model showed a better fit with the adsorption isotherm data with $\mathrm{R}^{2}$ greater than 0.95 . Kinetics of $\mathrm{MB}$ adsorption onto $\mathrm{SCH}$ and $\mathrm{NCH}$ followed the pseudo-second-order model. The maximum monolayer adsorption capacity was found to be 129 and $200 \mathrm{mg} / \mathrm{g}$ for SCH and $\mathrm{NCH}$, respectively. The present study showed that pretreated coffee husk waste can be used as an alternative for expensive adsorbents for the removal of dyes from wastewater.
\end{abstract}

Keywords Coffee husk $\cdot$ Pretreatment $\cdot$ Methylene blue $\cdot$ Adsorption $\cdot$ Optimisation

\section{Introduction}

Dyes are mostly organic molecules that can attach themselves to fabrics or surfaces to impart colour. Synthetic dyes are largely used in many sectors of advanced technology, such as in the textile, paper, plastics, food processing, leather tanning, printing, rubber and cosmetics industries $[1,2]$. Annually around $7 \times 10^{5}$ tons of commercial synthetic dyes is produced worldwide and the textile industry alone consumes more than 10,000 tons of dyes. Approximately $10-15 \%$ of the total dyestuff is utilised or released into the natural environment aesthetically unfavourable, and these recalcitrant and coloured dye molecules are not so easy to degrade biologically and are resistant to degrade on exposure to water, to light and also to various chemicals [3, 4]. Due to the toxic, carcinogenic, mutagenic and allergic nature of dyes, the direct discharge of untreated dye effluent can cause hazardous effects on living systems [5]. Several physicochemical and biological methods such as ozonation, chemical coagulation, chemical and electrochemical oxidation, photocatalysis, adsorption, and aerobic and anaerobic digestion are widely used

Electronic supplementary material The online version of this article (https://doi.org/10.1007/s42452-020-2603-9) contains supplementary material, which is available to authorized users.

$\triangle$ T. P. Krishna Murthy, tpk@live.in | 'Department of Biotechnology, M S Ramaiah Institute of Technology, Bangalore, Karnataka 560054, India. ${ }^{2}$ Visvesvaraya Technological University, Belagavi, Karnataka 590018, India. ${ }^{3}$ Department of Chemical Engineering, Siddaganga Institute of Technology, Tumakuru, Karnataka 572103, India. ${ }^{4}$ Department of Biotechnology, Siddaganga Institute of Technology, Tumakuru, Karnataka 572103, India. 
for removal of dyes from wastewater $[3,6,7]$. Among these methods, adsorption has emerged as an effective and economical alternative due to its ease of operation, simplicity of design, insensitivity to toxic substances and complete amputation of pollutants rather than getting degraded to hazardous intermediates $[8,9]$. The high cost and difficulty in regeneration are still concerned with the use of activated carbon, and it has motivated the research community to develop efficient and cost-effective alternative adsorbents for removal of dyes [5].

In recent days, agricultural industry by-products have attracted the research community in the field of the adsorption separation process for the removal of pollutants from the wastewater and key focus is because of the widespread availability of agricultural and allied industry residues. These adsorbents are biodegradable in nature and make it eco-friendly and also reduce the secondary pollution caused due to the disposal of adsorbent [10, 11]. Agricultural by-products are renewable in nature and available in bulk amount, and they are less expensive compared to other commercial adsorbents [12]. Agricultural waste such as coir pith, orange peel, banana peel, rice husk, straw, date pit, oil palm trunk fibre, durian peel, almond shell, pomelo peel, broad bean peel, peanut hull, Citrullus lanatus rind and coffee waste is widely studied in adsorption of dyes in their native and modified forms [10, 13-15]. These waste materials contain biopolymers and act as attractive alternative adsorbents due to their physicochemical characteristics, chemical stability and high reactivity towards water-soluble pollutants. These biopolymers also posses various functional groups such as alcohols, aldehydes, ketones, carboxylic, phenolic and ether that help in the removal of a wide range of pollutants [16].

Besides these advantages, agro-waste also possesses some disadvantages such as releasing soluble organic components present in biomass such as lignin, tannin, pectin and cellulose into the effluent stream and increases the biological oxygen demand (BOD), chemical oxygen demand (COD) and total organic carbon (TOC) and depletes oxygen content in the aquatic environment [17]. And also direct utilisation of biomass as adsorbent is many a time uneconomic due to low adsorption capacity and efficiency. These problems can be overcome by modifying or pretreating the biomass before employing in adsorption studies [18]. Physical and chemical treatments are generally used to improve the adsorption capacity by modifying the surface characteristics [19]. Physical pretreatment methods involve heating, autoclaving, freezedrying and boiling [20]. Chemical treatment majorly uses chemicals that includes solutions of alkali $\left(\mathrm{Na}_{2} \mathrm{CO}_{3}, \mathrm{NaOH}\right.$, $\left.\mathrm{Ca}\left(\mathrm{OH}_{2}\right)\right)$, mineral acid solutions $\left(\mathrm{HCl}, \mathrm{HNO}_{3}, \mathrm{H}_{2} \mathrm{SO}_{4}\right.$, tartaric acid, citric acid and formic acid), organic compounds (formaldehyde, $\mathrm{CH}_{3} \mathrm{OH}$, and epichlorohydrin) and oxidising agents $\left(\mathrm{H}_{2} \mathrm{O}_{2}, \mathrm{~K}_{2} \mathrm{MnO}_{4}\right.$ and propylene oxide) $[21,22]$.

The physical modification of biomass removes impurities, organic and mineral contents from the surface of agro-waste [23-25]. Autoclaving is one of the physical treatment techniques used by many researches to improve the adsorption properties of various biological materials such as fungi, algae and agricultural waste. Cells in the biomass subjected to autoclaving undergo rupture and denaturation and increase the surface area and porosity of the biomass and expose the hidden or embedded functional sites to the pollutants [26-28]. Among various chemical treatments, alkali pretreatment is widely used for surface modifications of agricultural waste to improve the adsorption efficiency and capacity. Alkali such as $\mathrm{NaOH}$ breaks down the covalent bond between components of lignocellulose by hemicellulose hydrolysis and lignin depolymerisation. This influences significantly on the molecular, supramolecular and morphological properties of cellulose matrix $[29,30]$. It will also influence the changes in crystallinity, pore architecture, accessibility, stiffness, unit cell structure and orientation of fibrils cellulosic fibres. $\mathrm{NaOH}$ treatment also eliminates the impurities such as natural fats, waxes and other low molecular weight compounds from the biomass and reveals the active functional groups which are easily accessible for pollutant adsorption [31, 32]. $\mathrm{NaOH}$ also improves the mechanical and chemical properties such as reactivity, durability and ion exchange capacity of natural material [33].

This study aimed at comparison of physical (autoclaving) and chemical treatment $(\mathrm{NaOH})$ of coffee husk on adsorption efficiency of methylene blue. The influence of process parameters such as $\mathrm{pH}$, adsorbent dose, initial dye concentration on $\mathrm{MB}$ adsorption capacity of $\mathrm{SCH}$ and $\mathrm{NCH}$ were optimised using response surface methodology.

\section{Materials and methods}

\subsection{Materials}

Coffee husk biomass was collected form coffee curing works located in Hassan, India. Analytical-grade sodium hydroxide, hydrochloric acid, sodium chloride, methylene blue (molecular formula - $\mathrm{C}_{16} \mathrm{H}_{18} \mathrm{CIN}_{3} \mathrm{~S}$, molecular weight $-319.85 \mathrm{~g} / \mathrm{mol}$ and $\lambda_{\max }-664 \mathrm{~nm}$ ) were procured from SD Fine-Chem Limited, India. Double distilled water was used throughout the studies.

\subsection{Preparation of adsorbent}

The coffee husk biomass was manually cleaned to remove foreign material and dried at $40{ }^{\circ} \mathrm{C}$ for $24 \mathrm{~h}$ to remove 
moisture. The dried biomass was ground in domestic blender to obtain approximately uniform-sized particles of $<400 \mu \mathrm{m}$. Physically treated biomass was prepared by an autoclaving mixture of coffee husk and double distilled water in the ratio of $1: 10$ for $1 \mathrm{~h}$ at $121^{\circ} \mathrm{C}$ and 15 Psi pressure. Chemically treated biomass was prepared by treating coffee husk with $2 \% \mathrm{NaOH}$ (coffee husk: $2 \% \mathrm{NaOH}=1: 10$ ratio) at $30^{\circ} \mathrm{C}$ for $2 \mathrm{~h}$. Both the adsorbents were washed repeatedly with double distilled water till the washed solutions turn colourless. The washed adsorbent was dried at $80^{\circ} \mathrm{C}$ and ground to obtain uniform-sized particles. The autoclaved and $\mathrm{NaOH}$-treated coffee husk biomass was named as $\mathrm{SCH}$ and $\mathrm{NCH}$, respectively.

\subsection{Instrumentation}

The Shimadzu UV-1800 double-beam UV-visible spectrophotometer was employed to determine the concentrations of methylene blue in the aqueous phase. SYSTRONICS pH meter ( $\mu \mathrm{C} \mathrm{pH}$ System 361) was used to measure $\mathrm{pH}$. Tescan-Mira-3 LMH field emission scanning electron microscope (FESEM) was used to study the morphological characteristics of $\mathrm{SCH}$ and $\mathrm{NCH}$. The functional groups present before and after adsorption on adsorbents are examined using Thermo NicoletAvatar-370 Fourier transform infrared spectrometer (FTIR) in the range of $4000-400 \mathrm{~cm}^{-1}$. The point of zero charge of the adsorbent was determined by solid addition method described elsewhere [34].

\subsection{Design of experiments}

Conventional one factor/variable at a time (OFAT/OVAT) optimisation approach that involves studying the effect of one factor keeping other factors constant is time-consuming and also not economical. OFAT methods of identifying optimum conditions require a larger number of experiments, and it ignores the interaction effect of parameters involved in the adsorption of dyes [35]. To overcome these problems, many researches are employing response surface methodology (RSM) to optimise the adsorption process. RSM is a combined statistical and mathematical method that uses the polynomial equation to study the relationship between the numerous independent parameters and also one or more responses [36]. Compared to conventional optimisation technique, RSM reduces the time and cost involved [37]. The most popular design strategy, central composite rotatable designs (CCRD), was employed in the present study to optimise the process parameters such as adsorbent dosage, initial dye concentration, $\mathrm{pH}$ and their interaction in adsorption of methylene blue onto physically $(\mathrm{SCH})$ and chemically treated $(\mathrm{NCH})$ coffee husk. The other parameters such as time, temperature and agitation speed were kept constant. The dye removal efficiency (\%) was considered as the response variable which is dependent on the selected independent variables and used to develop an empirical model.

The design of experiments for the adsorption study was constructed through Design-Expert V10 statistical software package to investigate the effect of different parameters and determine the best mathematical model. The range of parameters is chosen based on the preliminary studies done in the laboratory. CCRD comprises of three operations, viz. $2^{n}$ factorial runs, $2 n$ axial runs and $n C$ centre runs [38]. A total number of runs can be calculated from Eq. 1:

$N=2^{n}+2 n+n_{C}$

where $\mathrm{N}$ represents the total number of experimental runs, $\mathrm{n}$ indicates the number of independent variables and $\mathrm{n}_{\mathrm{C}}$ indicates the centre points. Based on this equation, CCRD matrix is obtained from the Design-Expert; a total of 17 experiments consist of eight factorial, six axial and three centres or replicate points for three independent variables. The coded values of independent variables as -1 and +1 represent eight factorial points at their lower and higher levels, respectively [39]. The six axial or outer points located at $-1.68(-\alpha)$ and $+1.68(a)$ and 0 represent the centre points used to examine the error in experimentation and to confirm the reproducibility of obtained data. The value of a characterise the distance of an axial point from the centre which makes the design rotatable and value of 1.68 is obtained from Eq. 2 :

$\propto=\left[2^{n}\right]^{1 / 4}$

where $2 n$ indicates the factorial runs [40]. The codes, range and level for three independent variables for $\mathrm{SCH}$ and $\mathrm{NCH}$ adsorbent are presented in Table 1, and CCRD design matrix for $\mathrm{SCH}$ and $\mathrm{NCH}$ adsorbent is given in Tables 2 and 3.

\subsection{Batch adsorption studies}

The adsorption of methylene blue onto $\mathrm{SCH}$ and $\mathrm{NCH}$ adsorbent was studied in batch mode. Adsorption experiments were carried out using a known concentration of $50 \mathrm{ml}$ methylene blue solution in a $250-\mathrm{ml}$ conical flask and agitated mechanically at $150 \mathrm{rpm}$ in an incubating shaker at a constant temperature $\left(30^{\circ} \mathrm{C}\right)$. Based on the CCRD design matrix provided in Tables 2 and 3, the adsorption experiments were conducted, and after required incubation time, the solution was centrifuged at 10,000 rpm. The residual dye concentration in the supernatant was measured at $664 \mathrm{~nm}$ using 
Table 1 Independent variables and their levels in the CCRD for MB adsorption onto SCH and $\mathrm{NCH}$

\begin{tabular}{|c|c|c|c|c|c|c|c|c|c|c|}
\hline \multirow[t]{3}{*}{ Variables } & \multicolumn{5}{|l|}{$\mathrm{SCH}$} & \multicolumn{5}{|l|}{$\mathrm{NCH}$} \\
\hline & \multicolumn{5}{|c|}{ Range and level } & \multicolumn{5}{|c|}{ Range and level } \\
\hline & $-a(-1.68)$ & 1 & 0 & 1 & $a(1.68)$ & $-a(-1.68)$ & 1 & 0 & 1 & $a(1.68)$ \\
\hline $\mathrm{pH}$ & 2 & 3.62 & 6 & 8.38 & 10 & 2 & 3.62 & 6 & 8.38 & 10 \\
\hline Initial dye concentration, mg/L & 20 & 36.22 & 60 & 83.78 & 100 & 25 & 50.34 & 87.50 & 124.66 & 150 \\
\hline Adsorbent dosage, $\mathrm{g} / \mathrm{L}$ & 0.2 & 0.36 & 0.60 & 0.84 & 1.0 & 0.1 & 0.18 & 0.30 & 0.42 & 0.5 \\
\hline
\end{tabular}

Table 2 CCRD matrix and experimental and predicted dye removal efficiencies of SCH

\begin{tabular}{|c|c|c|c|c|c|c|}
\hline \multirow[t]{2}{*}{ Run } & \multirow{2}{*}{$\begin{array}{l}\text { Factor } 1 \\
\text { A: } \mathrm{pH}\end{array}$} & \multirow{2}{*}{$\begin{array}{l}\text { Factor } 2 \\
\text { B: Initial dye } \\
\text { concentration, } \\
\mathrm{mg} / \mathrm{L}\end{array}$} & \multirow{2}{*}{$\begin{array}{l}\text { Factor } 3 \\
\text { C: SCH dosage, g/L }\end{array}$} & \multicolumn{3}{|c|}{ Dye removal efficiency (\%) } \\
\hline & & & & Experimental & Predicted & Relative error (\%) \\
\hline 1 & 10.00 & 60.00 & 0.60 & 87.25 & 83.39 & 4.42 \\
\hline 2 & 6.00 & 60.00 & 1.00 & 75.66 & 74.06 & 2.12 \\
\hline 3 & 8.38 & 83.78 & 0.36 & 48.21 & 49.27 & 2.20 \\
\hline 4 & 3.62 & 83.78 & 0.36 & 22.03 & 18.17 & 17.54 \\
\hline 5 & 6.00 & 60.00 & 0.60 & 71.75 & 69.91 & 2.55 \\
\hline 6 & 6.00 & 100.00 & 0.60 & 45.23 & 48.35 & 6.90 \\
\hline 7 & 3.62 & 83.78 & 0.84 & 43.64 & 42.81 & 1.92 \\
\hline 8 & 2.00 & 60.00 & 0.60 & 18.64 & 20.85 & 11.85 \\
\hline 9 & 6.00 & 60.00 & 0.60 & 65.58 & 69.91 & 6.61 \\
\hline 10 & 8.38 & 83.78 & 0.84 & 76.38 & 75.71 & 0.87 \\
\hline 11 & 3.62 & 36.22 & 0.84 & 55.91 & 56.01 & 0.19 \\
\hline 12 & 8.38 & 36.22 & 0.84 & 94.25 & 99.28 & 5.34 \\
\hline 13 & 6.00 & 60.00 & 0.60 & 72.13 & 69.91 & 3.08 \\
\hline 14 & 6.00 & 60.00 & 0.20 & 37.29 & 37.24 & 0.12 \\
\hline 15 & 3.62 & 36.22 & 0.36 & 36.85 & 38.67 & 4.95 \\
\hline 16 & 8.38 & 36.22 & 0.36 & 78.14 & 80.14 & 2.56 \\
\hline 17 & 6.00 & 20.00 & 0.60 & 90.18 & 85.41 & 5.29 \\
\hline
\end{tabular}

UV-VIS spectrophotometer. The dye removal efficiency and adsorption capacity were calculated using Eqs. 3-5 $[1,41]$.

DRE $=\frac{C_{0}-C_{t}}{C_{0}} \times 100$

$q_{t}=\frac{\left(C_{0}-C_{t}\right) V}{m}$

$q_{e}=\frac{\left(C_{0}-C_{e}\right) V}{m}$

where $C_{0}, C_{t}$ or $C_{e}$ are the initial and final concentration $(\mathrm{mg} / \mathrm{L})$ of MB dye in the solution. $\mathrm{q}_{\mathrm{t}}$ and $\mathrm{q}_{\mathrm{e}}$ are the adsorption capacities at time $t$ or equilibrium time.

\section{Results and discussion}

\subsection{Characterisation of adsorbent}

\subsubsection{SEM analysis}

Morphological structures of raw $(\mathrm{RCH})$, autoclaved $(\mathrm{SCH})$ and sodium hydroxide-treated $(\mathrm{NCH})$ coffee husk are illustrated in Fig. 1. These SEM micrographs provide useful information on the effect of pretreatment on the surface morphology of coffee husk. According to Fig. 1a, the surface of raw coffee husk is smooth and compact. Raw biomass has a comparatively less irregular structure including the pores. This nature of the surface might be due to adhesion of impurities and made the pores on the biomass smaller and blocked. However, from Fig. $1 \mathrm{~b}$ it is 
Table 3 CCRD matrix and experimental and predicted dye removal efficiencies of $\mathrm{NCH}$

\begin{tabular}{|c|c|c|c|c|c|c|}
\hline \multirow[t]{2}{*}{ Run } & \multirow{2}{*}{$\begin{array}{l}\text { Factor } 1 \\
\text { A: } \mathrm{pH}\end{array}$} & \multirow{2}{*}{$\begin{array}{l}\text { Factor } 2 \\
\text { B: Initial dye } \\
\text { concentration, } \\
\text { mg/L }\end{array}$} & \multirow{2}{*}{$\begin{array}{l}\text { Factor } 3 \\
\text { C: NCH dose, g/L }\end{array}$} & \multicolumn{3}{|c|}{ Dye removal efficiency (\%) } \\
\hline & & & & Experimental & Predicted & Relative error (\%) \\
\hline 1 & 6 & 87.5 & 0.3 & 78.5 & 72.74 & 7.34 \\
\hline 2 & 6 & 25 & 0.3 & 79.03 & 68.8 & 12.91 \\
\hline 3 & 3.62 & 50.34 & 0.42 & 48.31 & 50.57 & 4.68 \\
\hline 4 & 8.38 & 124.66 & 0.42 & 74.13 & 70.22 & 5.27 \\
\hline 5 & 6 & 87.5 & 0.3 & 69.97 & 72.74 & 3.96 \\
\hline 6 & 3.62 & 124.66 & 0.18 & 17.08 & 15.33 & 10.27 \\
\hline 7 & 3.62 & 50.34 & 0.18 & 13.22 & 23.1 & 74.79 \\
\hline 8 & 3.62 & 124.66 & 0.42 & 29 & 32.84 & 13.27 \\
\hline 9 & 6 & 150 & 0.3 & 37.08 & 38.82 & 4.72 \\
\hline 10 & 10 & 87.5 & 0.3 & 74.68 & 71.81 & 3.84 \\
\hline 11 & 8.38 & 124.66 & 0.18 & 44 & 47.72 & 8.45 \\
\hline 12 & 6 & 87.5 & 0.5 & 87.18 & 84.16 & 3.47 \\
\hline 13 & 6 & 87.5 & 0.1 & 47.58 & 42.15 & 11.42 \\
\hline 14 & 2 & 87.5 & 0.3 & 10.16 & 4.57 & 54.98 \\
\hline 15 & 8.38 & 50.34 & 0.18 & 63.55 & 65.68 & 3.35 \\
\hline 16 & 6 & 87.5 & 0.3 & 71.14 & 72.74 & 2.26 \\
\hline 17 & 8.38 & 50.34 & 0.42 & 90.39 & 98.12 & 8.55 \\
\hline
\end{tabular}

evident that there is no obvious distinction between the morphology of $\mathrm{RCH}$ and $\mathrm{SCH}$. Compared to $\mathrm{RCH}$ and $\mathrm{SCH}$, the $\mathrm{NCH}$ (Fig. 1C) surface was highly rough and changed to porous structure with cavities, ridges and varied heterogeneous pores. This attribute is due to the removal of impurities present and disintegration of polymers present in the coffee husk biomass. The $\mathrm{NaOH}$ treatment induces the cracking in the biomass and increases the roughness. The removal of water-soluble compounds also contributes to an increase in surface roughness and porosity. This heterogeneous nature of adsorbent provides more surface area with high chances of dyes trapped and adsorbed on the surface [30, 33, 42].

\subsubsection{FTIR analysis}

The FTIR spectra of raw coffee husk biomass are presented in Fig. 2. The peaks close to $3410 \mathrm{~cm}^{-1}$ and $1052 \mathrm{~cm}^{-1}$ represent the stretching vibrations of $-\mathrm{O}-\mathrm{H}$ and $\mathrm{C}-\mathrm{O}-\mathrm{C}$ present in cellulose and lignin in the coffee husk. The welldefined peaks at 2928 and $1376 \mathrm{~cm}^{-1}$ are the characteristic peaks for $\mathrm{C}-\mathrm{H}$ bond stretching and bending vibrations, respectively. The peaks located at 1746 and $1628 \mathrm{~cm}^{-1}$ are attributed to stretching vibrations of aldehydes and ketones, and peak at $1429 \mathrm{~cm}^{-1}$ can be assigned to carboxyl group C-O bond stretching vibration. Peaks at 1248 and $1437 \mathrm{~cm}^{-1}$ correspond to $\mathrm{C}-\mathrm{N}$ stretching vibration of the amine group and $\mathrm{O}-\mathrm{H}$ bending vibration of the carboxylic group, respectively [43-48].
FTIR spectra of SCH are illustrated in Fig. 3. Most of the peaks present in the raw $\mathrm{CH}$ spectra are also present in the $\mathrm{SCH}$ spectra, but with the reduced intensities. It shows that treatment has removed the leachables from the biomass and exposed the buried residues present in the biomass due to autoclaving of biomass. Various functional groups present on the $\mathrm{SCH}$ biomass have facilitated the adsorption of MB. The MB-adsorbed $\mathrm{SCH}$ FTIR spectra given in Fig. 3 show a distinct peak at 1330 and $1384 \mathrm{~cm}^{-1}$ which indicates the presence of $-\mathrm{C}-\mathrm{N}$ bonds of aromatic amines attributed to adsorption of $\mathrm{MB}$ on $\mathrm{SCH}$. Also, the increase in peak intensity at $1597 \mathrm{~cm}^{-1}$ after adsorption indicates an increase in the number of $-\mathrm{C}=\mathrm{C}$ bonds due to cyclic alkene probably due to adsorption of MB $[49,50]$.

FTIR spectra of sodium hydroxide-treated coffee husk biomass are given in Fig. 4, and there is a significant change in the spectra of raw and $\mathrm{NaOH}$-treated coffee husk biomass. The disappearance of peak at $1746 \mathrm{~cm}^{-1}$ attributes uronic ester groups and indicates the substantial reduction in lignin and hemicellulose content in the coffee husk biomass [51,52]. Some of the new peaks in the spectra of $\mathrm{NCH}$ clarify the modification of raw coffee husk. From Fig. 4, peak $1328 \mathrm{~cm}^{-1}$ indicates the $-\mathrm{C}-\mathrm{N}$ bonds of the methylene blue aromatic amine and clarifies the adsorption. 

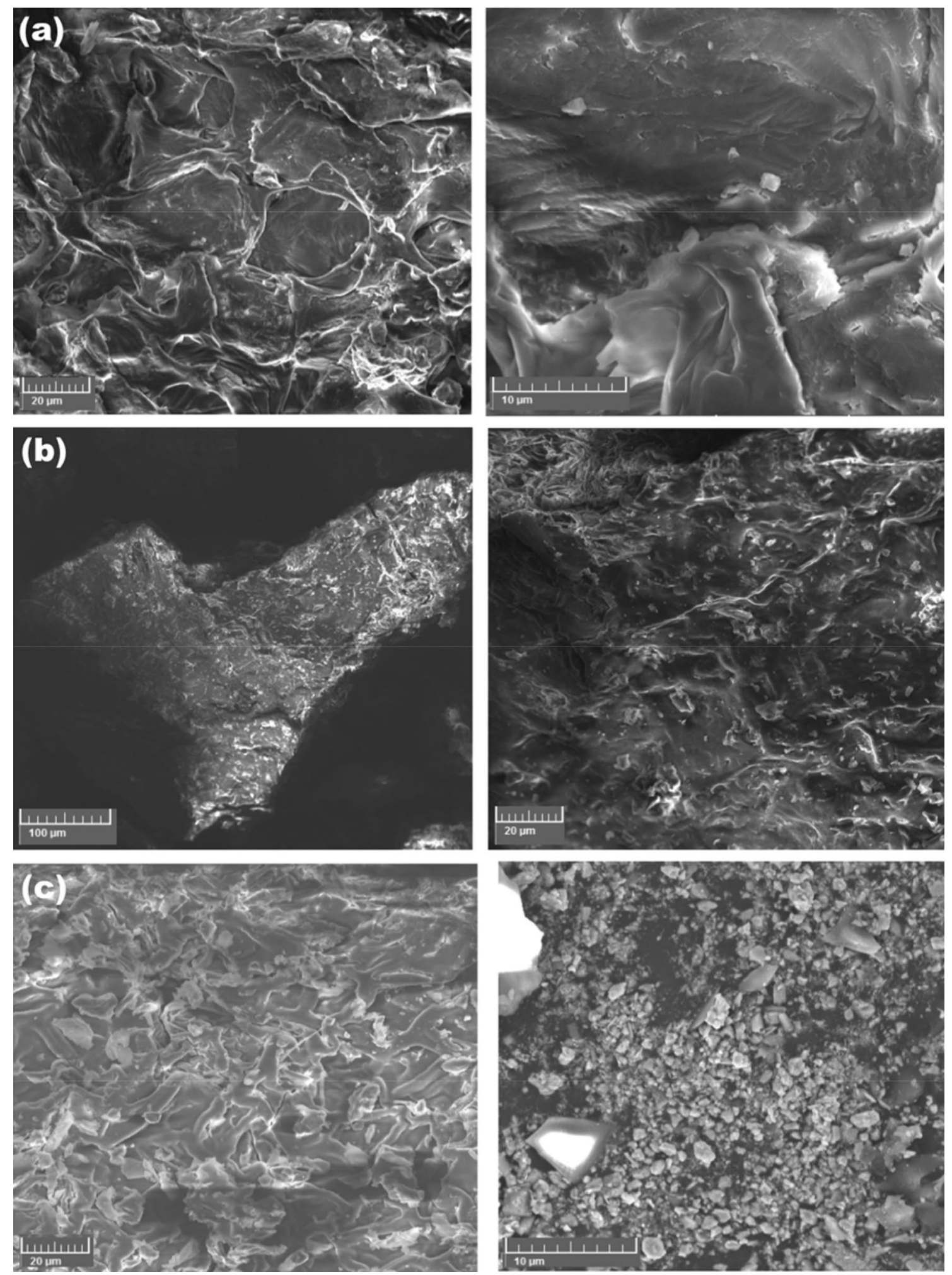

Fig. 1 SEM micrographs of a raw coffee husk, b SCH, $\mathbf{c ~ N C H}$ 


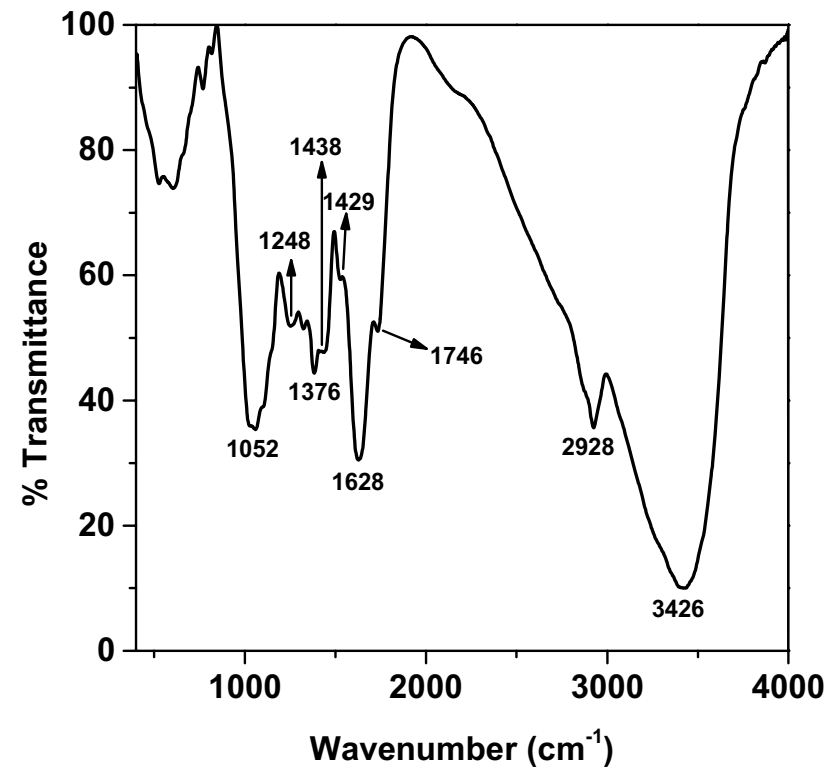

Fig. 2 FTIR spectrum of raw coffee husk

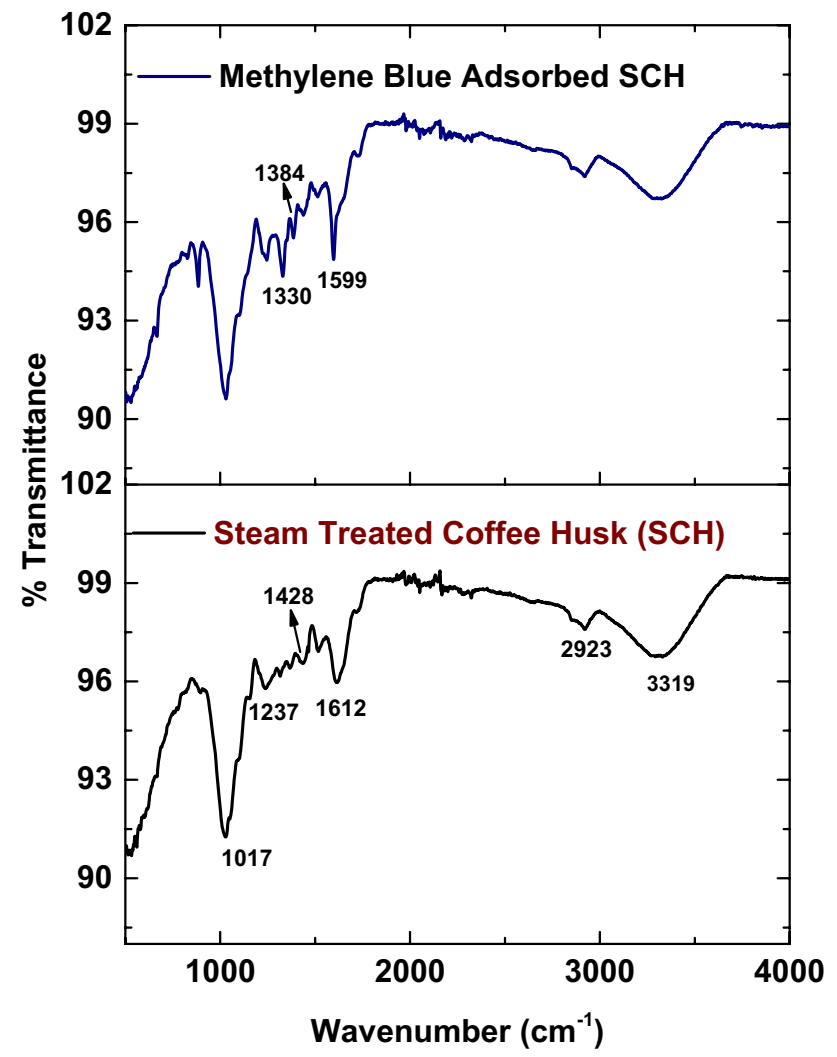

Fig. 3 FTIR spectra of SCH and MB-adsorbed SCH

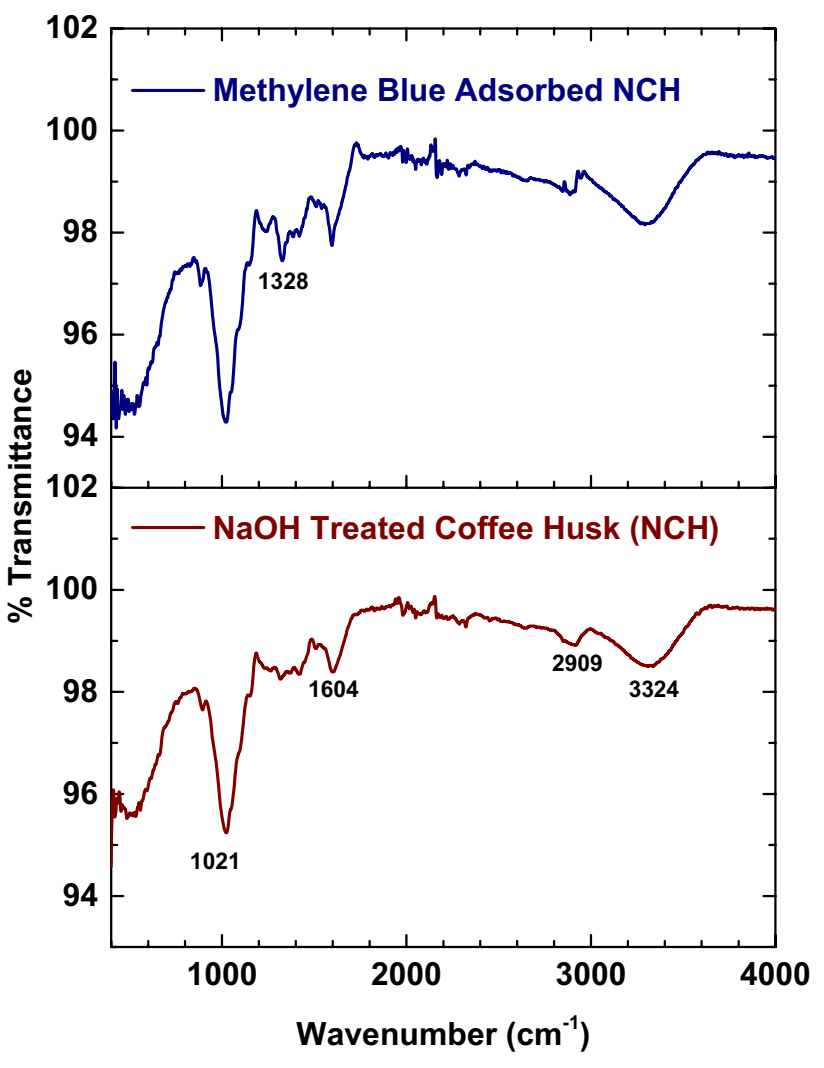

Fig. 4 FTIR spectra of $\mathrm{NCH}$ and MB-adsorbed $\mathrm{NCH}$

\subsection{Optimisation of process parameters}

\subsubsection{Development of the regression model}

In the CCRD, three independent parameters, viz. $\mathrm{pH}$, initial $\mathrm{MB}$ concentration and adsorbent dosage, were prescribed into five levels and were selected for each of the experiments. The experimental design suggested by Design-Expert V10 software along with actual and predicted dye removal efficiency for $\mathrm{SCH}$ and $\mathrm{NCH}$ adsorbent is presented in Tables 2 and 3. Analysis tools available in the Design-Expert were employed to analyse the experimental data and fitted to the polynomial models which explains the effect of linear, two-factor interaction and quadratic over the responses. The best model is selected according to the significant model $p$ value, insignificant lack of fit value and maximum values of adjusted and predicted $R^{2}$ values $[53,54]$. The model fit summary given in Tables $\mathrm{S} 1$ and $\mathrm{S} 2$ shows the results of statistical analysis of the selected models at the confidence level of $95 \%$ ( $p$-value $<0.05)$. Among all the models fitted, the quadratic model is of good choice since the lack of fit value was insignificant with higher values of adjusted and predicted $R^{2}$ values for both the adsorbents. Another important parameter that supports the selection and validation of 
the best model is predicted residual error sum of squares (PRESS), and it is a measure between the actual and predicted values of the response. PRESS can be calculated from the mean square of the differences between actual and predicted responses, and the best model has the lowest values of PRESS values $[55,56]$. In the present study,

Table 4 Regression statistics of quadradic model

\begin{tabular}{lrlrlrrr}
\hline SCH & \multicolumn{7}{c}{ NCH } \\
\hline Std. Dev. & 4.34 & R-Squared & 0.9851 & Std. Dev. & 7.79 & R-Squared \\
Mean & 59.95 & Adj R-Squared & 0.9659 & Mean & 57.52 & Adj R-Squared & 0.9496 \\
C.V. \% & 7.23 & Pred R-Squared & 0.9011 & C.V. \% & 13.54 & Pred R-Squared & 0.7120 \\
Press & 873.36 & Adeq Precision & 24.3872 & Press & 3462.83 & Adeq Precision & 16.9890 \\
-2 Log Likelihood & 83.04 & BIC & 111.3744 & -2 Log Likelihood & 125.00 & BIC & 154.9525 \\
AICC & 139.71 & & & AICc & 169.44 & \\
\hline
\end{tabular}

Table 5 Analysis of variance of the response surface quadratic model for the prediction of dye removal efficiency of $\mathrm{SCH}$
Table 6 Analysis of variance of the response surface quadratic model for the prediction of dye removal efficiency of $\mathrm{NCH}$

\begin{tabular}{|c|c|c|c|c|c|c|}
\hline Source & Sum of squares & Df & Mean square & F value & $P$-value $($ Prob $>\mathrm{F})$ & Significance \\
\hline Model & 8698.69 & 9 & 966.52 & 51.39 & $<0.0001$ & Significant \\
\hline A-pH & 4721.32 & 1 & 4721.32 & 251.03 & $<0.0001$ & \\
\hline $\begin{array}{l}\text { B-Initial dye } \\
\text { concentra- } \\
\text { tion }\end{array}$ & 1658.13 & 1 & 1658.13 & 88.16 & $<0.0001$ & \\
\hline C-SCH dose & 1636.21 & 1 & 1636.21 & 87.00 & $<0.0001$ & \\
\hline$A B$ & 53.71 & 1 & 53.71 & 2.86 & 0.1349 & \\
\hline$A C$ & 1.63 & 1 & 1.63 & 0.09 & 0.7771 & \\
\hline BC & 26.67 & 1 & 26.67 & 1.42 & 0.2725 & \\
\hline$A^{2}$ & 446.03 & 1 & 446.03 & 23.72 & 0.0018 & \\
\hline$B^{2}$ & 12.99 & 1 & 12.99 & 0.69 & 0.4333 & \\
\hline$C^{2}$ & 286.67 & 1 & 286.67 & 15.24 & 0.0059 & \\
\hline Residual & 131.65 & 7 & 18.81 & & & \\
\hline Lack of fit & 104.63 & 5 & 20.93 & 1.55 & 0.4370 & Not significant \\
\hline Pure error & 27.03 & 2 & 13.51 & & & \\
\hline Cor total & 8830.35 & 16 & & & & \\
\hline
\end{tabular}

\begin{tabular}{lrrrrrl}
\hline Source & Sum of squares & Df & Mean square & F value & $P$-value Prob $>$ F & Significance \\
\hline Model & $11,415.90$ & 9 & 1268.43 & 20.92 & $<0.0001$ & Significant \\
A-pH & 5456.39 & 1 & 5456.39 & 89.97 & $<0.0001$ & \\
B-Initial dye & 1086.57 & 1 & 1086.57 & 17.92 & 0.0017 & \\
$\begin{array}{l}\text { concentra- } \\
\text { tion }\end{array}$ & & & & & & \\
C-NCH dose & 2130.58 & 1 & 2130.58 & 35.13 & 0.0001 & \\
AB & 51.82 & 1 & 51.82 & 0.85 & 0.3770 & \\
AC & 12.42 & 1 & 12.42 & 0.20 & 0.6606 & \\
BC & 49.45 & 1 & 49.45 & 0.82 & 0.3878 & \\
A $^{2}$ & 2150.81 & 1 & 2150.81 & 35.47 & 0.0001 & \\
B $^{2}$ & 644.66 & 1 & 644.66 & 10.63 & 0.0086 & \\
C $^{2}$ & 165.61 & 1 & 165.61 & 2.73 & 0.1294 & \\
Residual & 606.44 & 10 & 60.64 & & & \\
Lack of fit & 399.74 & 5 & 79.95 & 1.93 & 0.2433 & Not significant \\
Pure error & 206.71 & 5 & 41.34 & & & \\
Cor Total & $12,022.34$ & 19 & & & & \\
\hline
\end{tabular}


compared to the other three models, the quadratic model has the lower values of PRESS for both the adsorbents. The detailed regression statistics are provided in Table 4.

\subsubsection{Statistical analysis (ANOVA)}

The results of ANOVA for a selected quadratic model with estimated coefficients are summarised in Tables 5 and 6 for $\mathrm{SCH}$ and $\mathrm{NCH}$, respectively. The ANOVA results show that the developed models are highly significant with $p<0.0001$ for the adsorbents. Larger model F-value for $\mathrm{SCH}$ and $\mathrm{NCH}$ further confirms the significance of the model, and there is only a $0.01 \%$ chance that an F-value this large could occur due to noise. The model terms are significant if the values of prob $>\mathrm{F}$ less than 0.05 and values more than 0.1 indicate model terms are not significant. In the case of $\mathrm{SCH}$ adsorbent, the model terms $A, B, C, A^{2}$, $C^{2}$ are significant model terms, but for $\mathrm{NCH}$ adsorbent $A, B$, $C, A^{2}$ and $B^{2}$ terms are significant model terms. The values of prob $>\mathrm{F}$ greater than 0.1 indicate the model terms do not significantly influence the process of methylene blue dye adsorption efficiency. The lack of fit F-value of 1.55 and 1.93 for $\mathrm{SCH}$ and $\mathrm{NCH}$, respectively, specifies that the lack of fit F-value is not significantly relative to the pure error. And also $p>F$ value greater than 0.05 also justifies the lack of fit of the model is not significant and one has to select the model with insignificant lack of fit. For both adsorbents, the difference 0.2 indicates that predicted $R^{2}$ is in reasonable agreement with the adjusted $R^{2}$. For a good model, the signal-to-noise ratio measured from adequate precision greater than 4 is desirable. The large value of 24.39 and 16.99 , respectively, for $\mathrm{SCH}$ and $\mathrm{NCH}$ indicates the adequate signal and can be used to navigate the design space. The final model obtained based on the ANOVA in terms of actual variables representing the dye removal efficiency (DRE) of $\mathrm{SCH}$ and $\mathrm{NCH}$ is given in Eq. 6 and 7, respectively:

$$
\begin{aligned}
& \mathrm{DRE}_{S C H}=-57.76+23.43 A-0.15 B+128.84 C-0.05 A B+0.80 A C \\
& +0.32 B C-1.11 A^{2}-1.90 \times 10^{-3} B^{2}-89.14 C^{2} \\
& \mathrm{DRE}_{\mathrm{NCH}}=-146.54+35.52 A-0.95 B+271.65 C \\
& \quad-0.03 A B+4.40 A C-0.56 B C \\
& \quad-2.16 A^{2}-4.84 \times 10^{-3} B^{2}-239.71 C^{2}
\end{aligned}
$$

These equations in terms of actual factors can be used to predict the dye removal efficiency of the adsorbent for given values of the independent variable. In the above equation, positive sign of constants indicates the synergetic effect of variables improving the adsorption capacity by favouring the adsorption process. The negative value shows that the variables have an antagonistic effect on the adsorption capacity and unfavourable to the adsorption process $[57,58]$.

Figure $\mathrm{S} 1$ shows the plot of residuals' normal probability (\%) and the internally studentised residuals. It is observed that the residual distribution is very normal without significant outliers with averaging all the points on the straight line. This attribute indicates that there are no necessary of response transformation and no apparent problem with normality $[59,60]$. The relationship between the experimental and predicted dye removal efficiencies is shown in Figure S2 and indicates that all the model points fall on a straight line showing predicted values were best fitted with actual values. Hence, the developed response surface model developed in this study can be satisfactorily used in the optimisation of the process for adsorption of MB onto $\mathrm{SCH}$ and $\mathrm{NCH}$ adsorbent.

\subsection{Response surface analysis}

\subsubsection{Main effects of parameters on adsorption efficiency}

The perturbation plots assist in comparing the effects of the selected parameters at a specific point in the design space $[61,62]$. The response can be plotted by changing only one parameter over the range while keeping all the other parameters constant. The Design-Expert software used in this study sets the midpoint (coded 0 ) as the reference point for all the factors. Figure S3 shows the perturbation plot employed to investigate the effect of independent variables simultaneously on MB removal efficiency of $\mathrm{SCH}$ and $\mathrm{NCH}$ adsorbent. In the present study, the variables such as $\mathrm{pH}$, initial dye concentration and adsorbent dosage are considered for obtaining maximum dye removal efficiency. A sharp curvature of all the parameters indicates that the dye removal efficiency is very sensitive to these factors. The plateau-like curve of initial dye concentration for $\mathrm{SCH}$ indicates insensitivity of the dye removal efficiency in working concentration levels.

The initial $\mathrm{pH}$ of dye solution is a vital parameter in the adsorption studies, which significantly affects the removal capacity of the adsorbent, and it is a necessity to find the optimum $\mathrm{pH}$ of the adsorption processes. In water treatment, the $\mathrm{pH}$ of the solution varies the degree of ionisation of the dye molecules and also the surface properties of the adsorbent. Figures S4(a) and S5(a) show the effect of $\mathrm{pH}$ on $\mathrm{MB}$ adsorption capacity onto $\mathrm{SCH}$ and $\mathrm{NCH}$, respectively, at midpoints of initial dye concentration and adsorbent dosage. From these results, it shows that the dye removal efficiency of methylene blue significantly increased as there is an increase in $\mathrm{pH}$ for both $\mathrm{SCH}$ and $\mathrm{NCH}$. But for $\mathrm{NCH}$ after $\mathrm{pH} 8$, the dye removal efficiency was slightly increased. This attribute can be explained from the point of zero charge value of $\mathrm{SCH}$ and $\mathrm{NCH}$ adsorbent, and the $\mathrm{pH}_{\mathrm{pzc}}$ 
value was found to be 4.35 and 6.95 for $\mathrm{SCH}$ and $\mathrm{NCH}$, respectively (Fig. 5). For cationic dyes, the maximum dye removal efficiency has occurred at $\mathrm{pH}$ greater than $\mathrm{pH}_{\mathrm{pzc}}$ and anionic dyes show better efficiency at $\mathrm{pH}<\mathrm{pH}_{\mathrm{pzc}}$. This is because, at $\mathrm{pH}$ values less than $\mathrm{pH}_{\mathrm{pzc}}$ the $\mathrm{H}^{+}$ion concentration in the solution increases, and the adsorbent surface acquires positive charge by $\mathrm{H}^{+}$ion adsorption ion on the surface from the solution. In other words, surface adsorbent gets protonated in acidic medium and develop strong electrostatic forces of attraction between the anionic dye and adsorbent surface. The $\mathrm{pH}$ value above the point of zero charge, $\mathrm{OH}^{-}$ions increases and the adsorbent surface will be negatively charged. This developed the attractive force between the positively charged cationic dye such as $\mathrm{MB}$ and negatively charged $\mathrm{SCH}$ and $\mathrm{NCH}$ adsorbent $[63,64]$.

The effect of initial MB concentration at midpoints of $\mathrm{pH}$ and adsorbent dosage on $\mathrm{SCH}$ and $\mathrm{NCH}$ is presented in Figures S4(b) and S5(b), respectively. From this, it is revealed that dye removal efficiency decreases with the
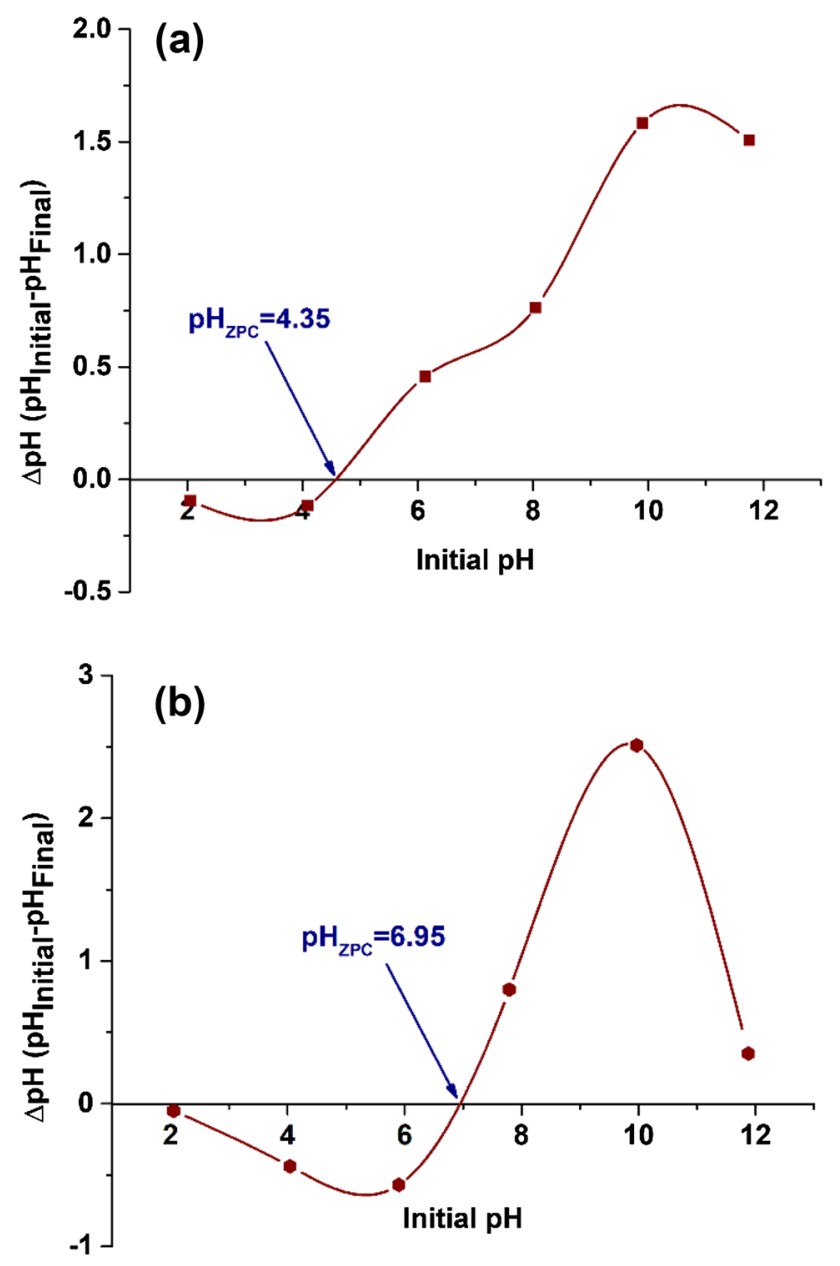

Fig. 5 Point of Zero Charge $\mathbf{a} \mathrm{SCH}$ and $\mathbf{b} \mathrm{NCH}$ increase in initial MB concentration. This is ascribed due to the availability of many unoccupied adsorption sites at lower concentration that facilitates the greater adsorption efficiency. At higher concentration, these necessary active sites will be lacking and competition may exist between dye molecules which reduces the dye removal efficiency $[65,66]$. From Figures S4(c) and S5(c), it is evident that adsorbent dosage has a significant effect on the $\mathrm{MB}$ removal efficiency onto $\mathrm{SCH}$ and $\mathrm{NCH}$. The increase in dye removal efficiency is due to a proportional increase in the number of available adsorption sites with an increase in adsorbent dosage [34].

\subsubsection{Interaction Effect of parameters on adsorption efficiency}

The influence of selected process parameters on the MB dye removal efficiency of $\mathrm{SCH}$ and $\mathrm{NCH}$ is studied using surface and counterplots given in Fig. 6 and 7. The interactive effect of $\mathrm{pH}$ and initial dye concentration presented in Figs. $6 \mathrm{a}$ and $7 \mathrm{a}$ shows that increase in $\mathrm{pH}$ increased the removal efficiency for both the adsorbents, but after $\mathrm{pH}$ 8, the removal efficiency decreased slightly for $\mathrm{NCH}$ adsorbent. The increased in initial dye concentration significantly decreased the dye removal efficiency at constant adsorbent dosage. It indicates the unavailability of adsorption sites at higher dye concentration. The interaction of $\mathrm{pH}$ and adsorbent dosage shown in Figs. $6 \mathrm{~b}$ and $7 \mathrm{~b}$ indicates the $\mathrm{pH}$ and adsorbent dosage has a synergetic effect on dye removal efficiency. Besides, the interactive effect of initial dye concentration and the adsorbent dosage is given in Figs. $6 c$ and $7 c$ suggesting that MB initial concentration has an antagonistic effect on dye removal efficiency.

\subsubsection{Numerical optimisation and validation of the model}

The optimum condition of the selected process parameters to obtain maximum dye removal efficiency was determined based on the desirability function. Numerical optimisation available in Design-Expert was employed in identifying the specific points that maximise the value of desirability function. According to the calculations, chosen optimum condition at the desirability value of 1 is given in Table 7. The reliability of predicted response at optimum conditions is validated by conducting experiments in duplicates, and the data are presented in Table 7. The experimental dye removal efficiencies are closer to the predicted dye removal efficiencies and confirm the validity of the proposed quadratic model to optimise the $\mathrm{pH}$, initial dye concentration and adsorbent dosage on the adsorption of $\mathrm{MB}$ onto $\mathrm{SCH}$ and $\mathrm{NCH}$. 
(a)

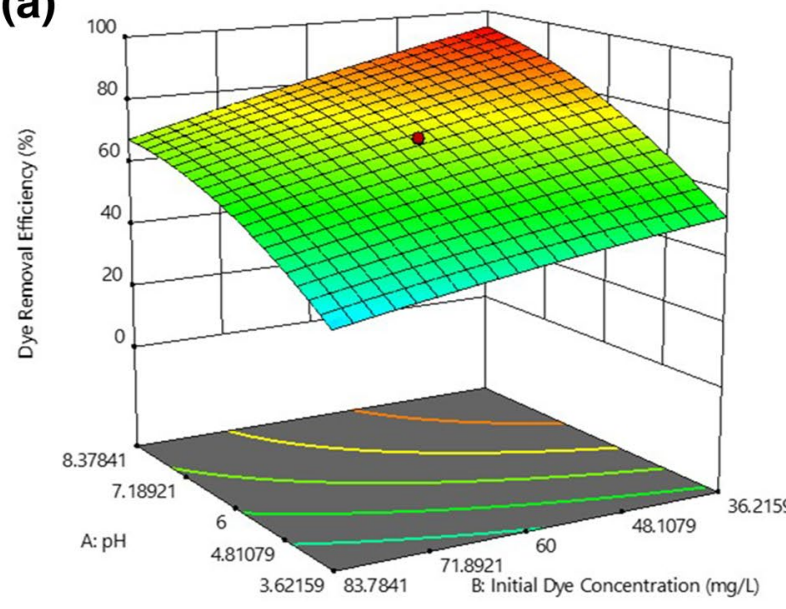

(b)

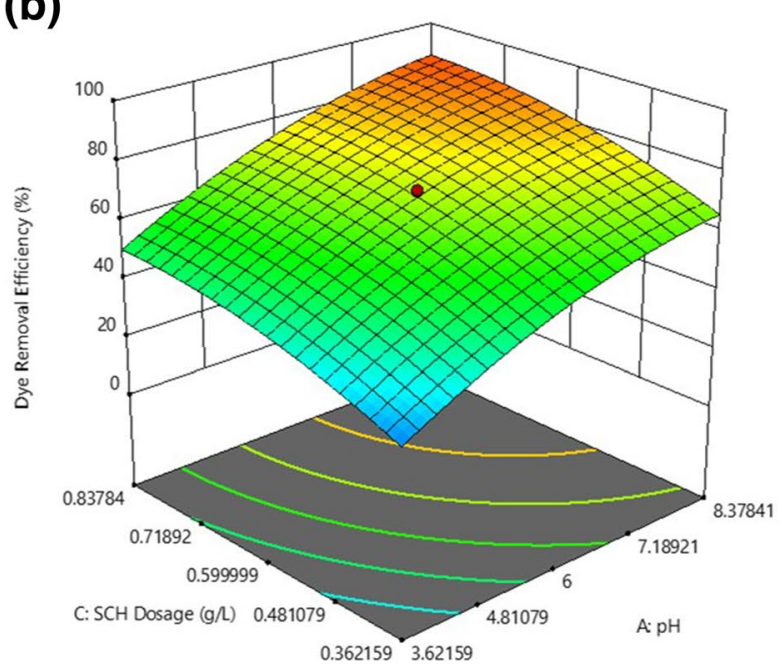

(c)

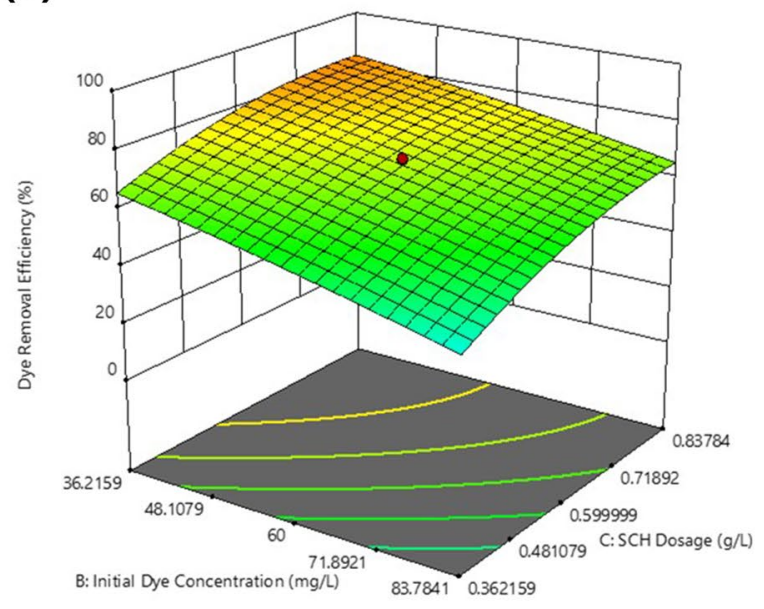

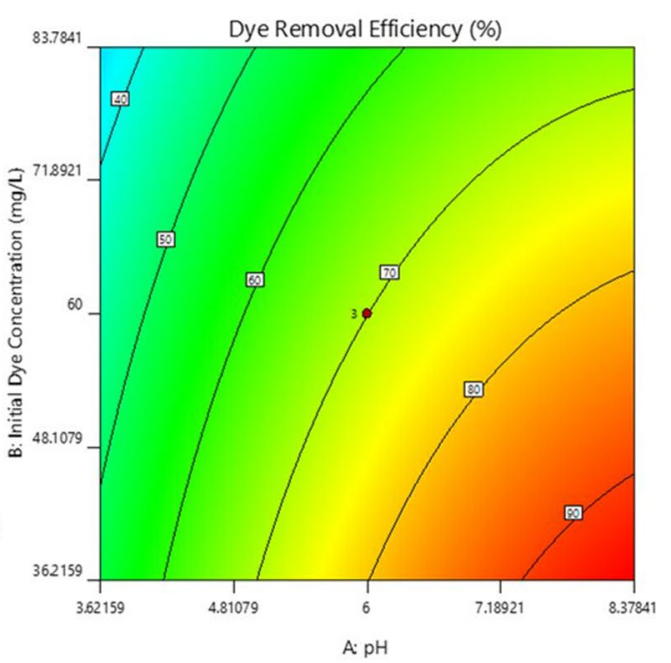
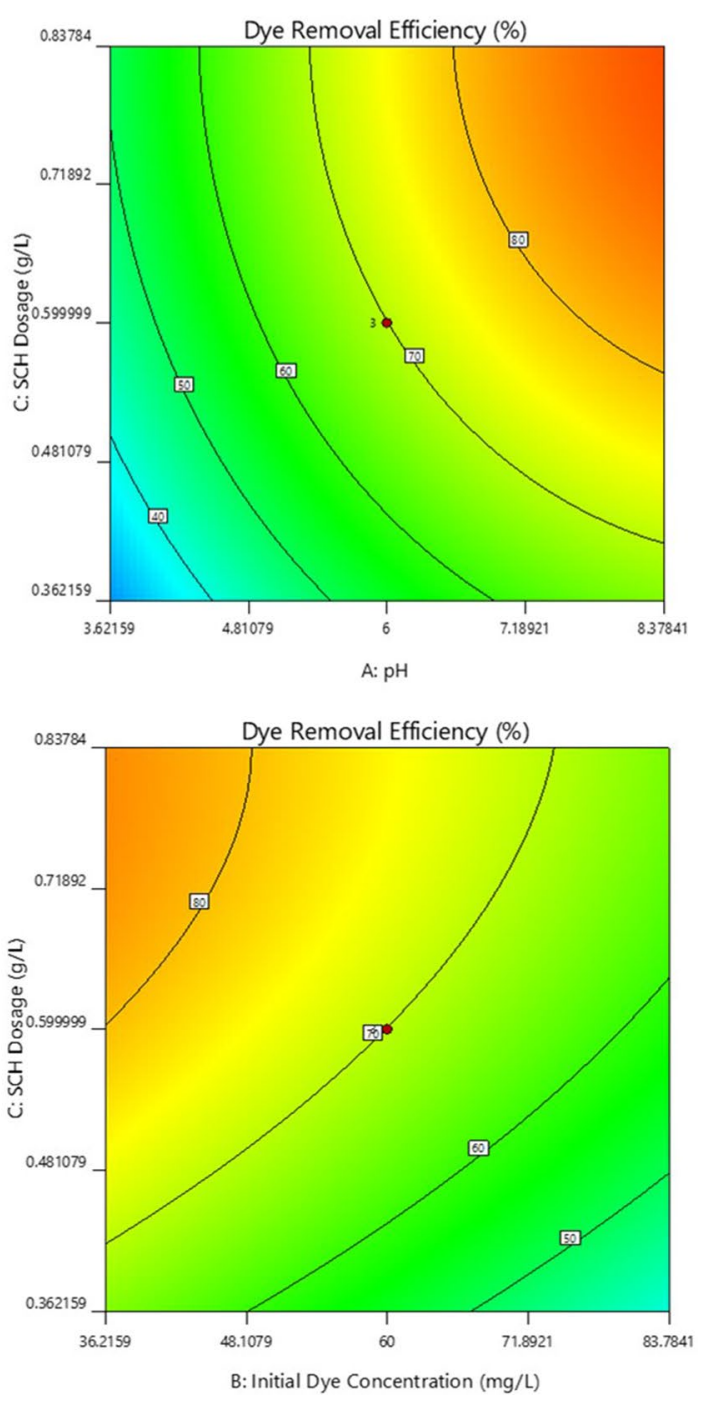

Fig. 6 Response surface plots for SCH adsorbent 
(a)

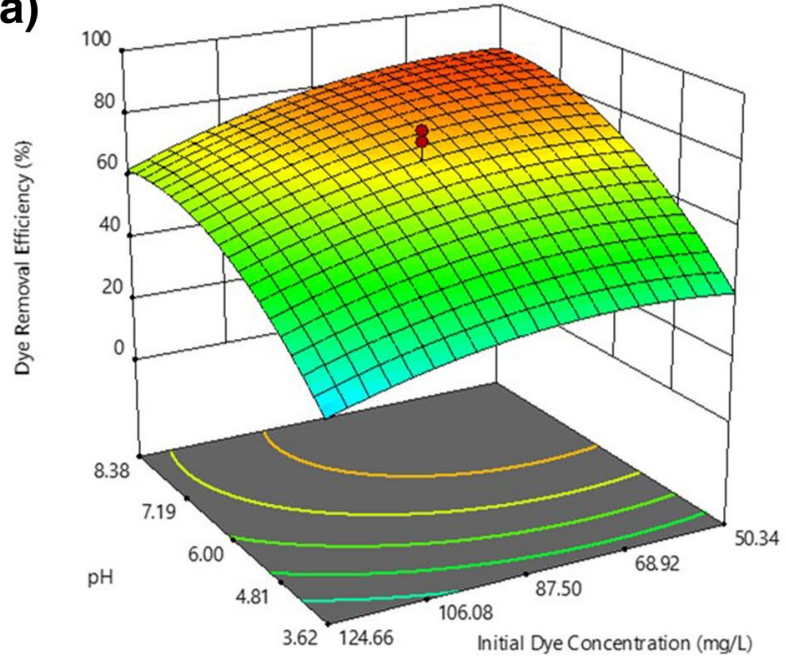

(b)

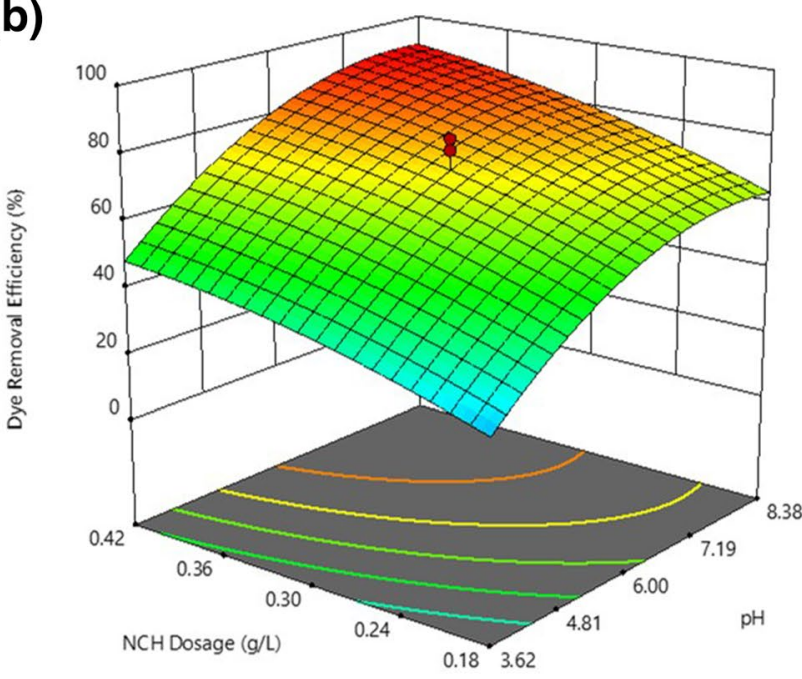

(c)

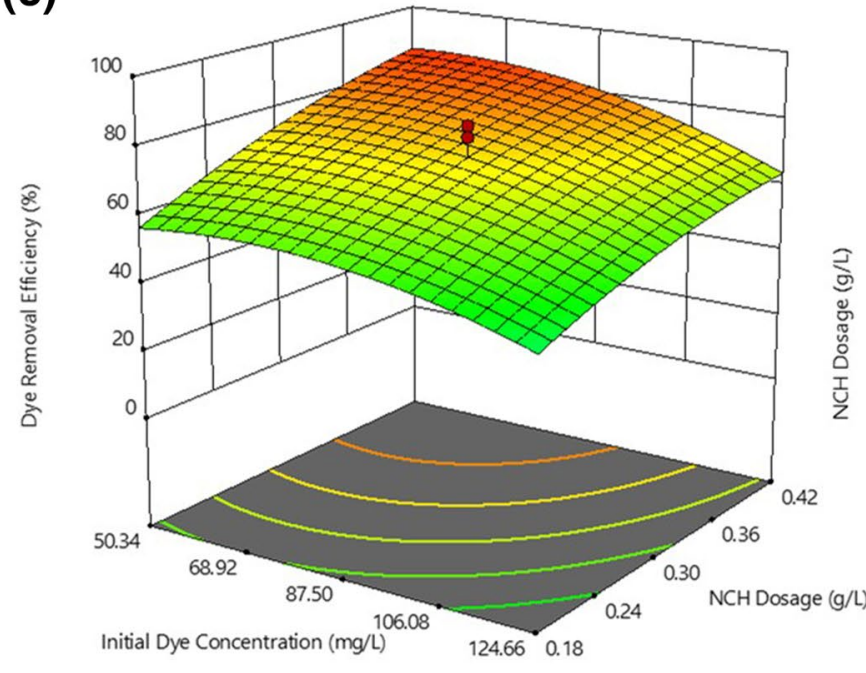

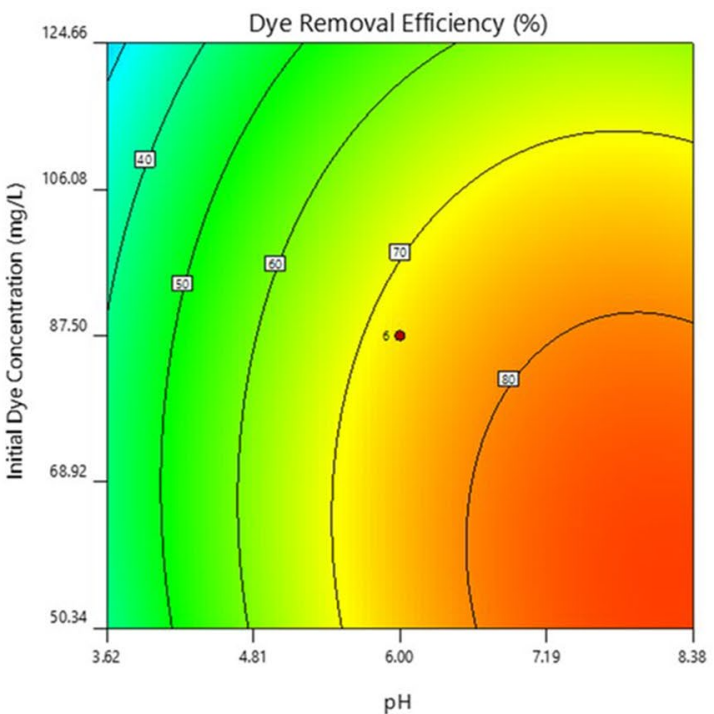

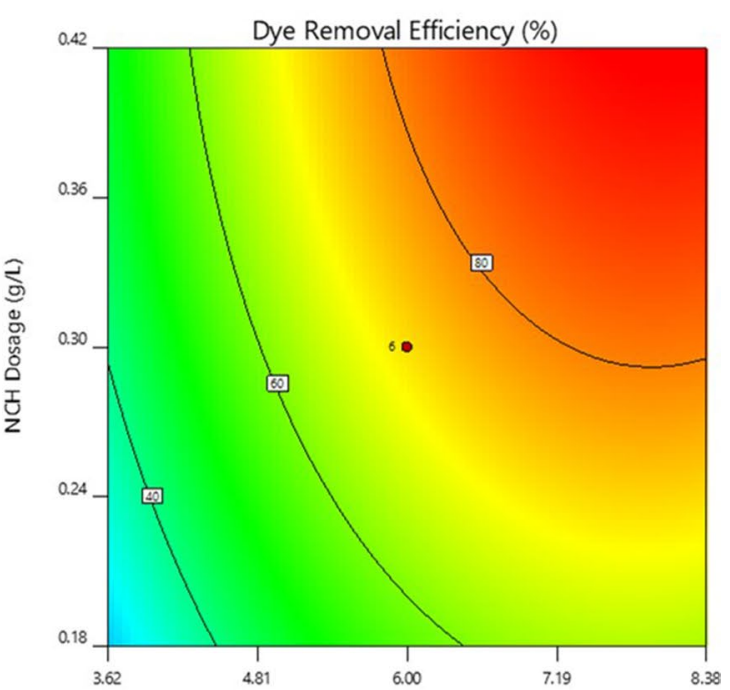

$\mathrm{pH}$

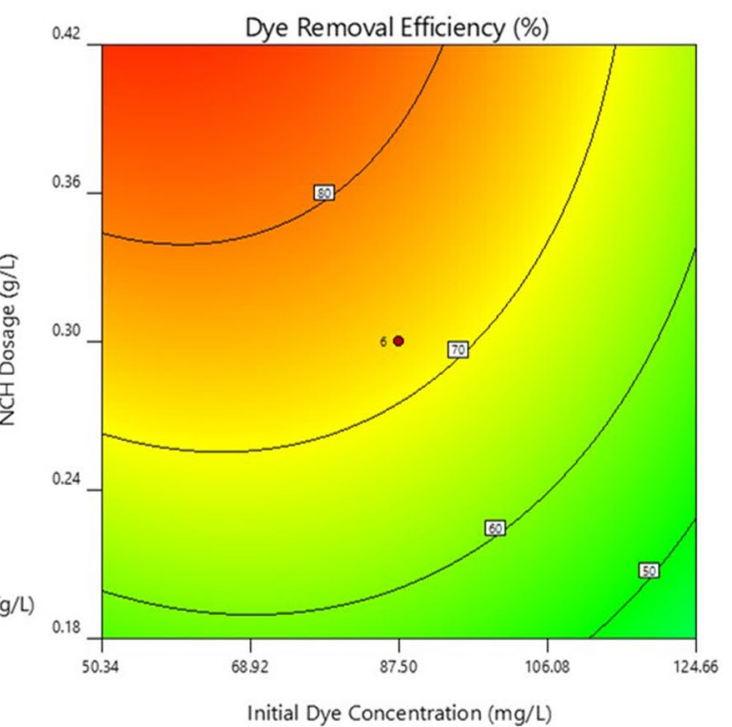

Fig. 7 Response surface plots for $\mathrm{NCH}$ adsorbent

\section{SN Applied Sciences}


Table 7 Optimum experimental conditions for methylene blue removal using $\mathrm{SCH}$ and $\mathrm{NCH}$ adsorbent

\begin{tabular}{|c|c|c|c|c|c|c|c|}
\hline \multirow[t]{2}{*}{ Adsorbent } & \multicolumn{3}{|c|}{ Predicted optimum values } & \multirow[t]{2}{*}{ Desirability } & \multirow[t]{2}{*}{$\mathrm{DRE}_{\text {Predicted }}$} & \multirow[t]{2}{*}{ DRE experimental } & \multirow{2}{*}{$\begin{array}{l}\text { Residual } \\
\text { error } \\
(\%)\end{array}$} \\
\hline & $\mathrm{pH}$ & $\begin{array}{l}\text { Initial dye } \\
\text { concentration, } \\
\mathrm{mg} / \mathrm{L}\end{array}$ & $\begin{array}{l}\text { Adsorbent } \\
\text { dosage, g/L }\end{array}$ & & & & \\
\hline $\mathrm{SCH}$ & 7.637 & 37.786 & 0.740 & 1 & 94.629 & 93.528 & 1.16 \\
\hline $\mathrm{NCH}$ & 7.914 & 84.495 & 0.406 & 1 & 91.298 & 92.482 & 1.30 \\
\hline
\end{tabular}

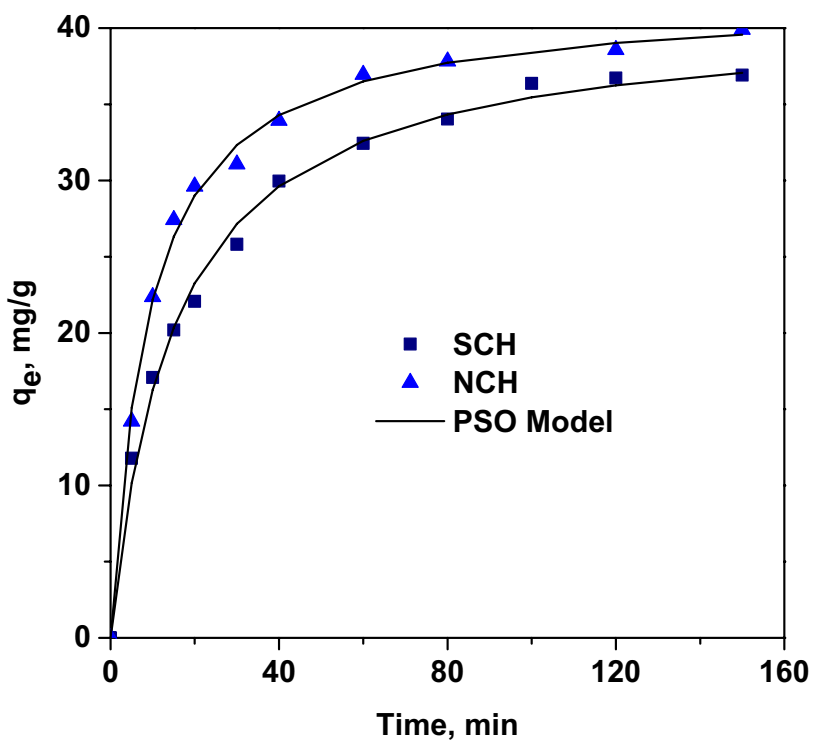

Fig. 8 PSO plot for adsorption of $\mathrm{MB}$ onto $\mathrm{SCH}$ and $\mathrm{NCH}$

\subsubsection{Adsorption kinetics}

Kinetics analysis of the adsorption process explains the rate of uptake of adsorbent and also aids to determine the residence time of the adsorption. It is one of the important characteristics in defining the efficiency of adsorption [5]. The effect of time on adsorption of $\mathrm{MB}$ on $\mathrm{SCH}$ and $\mathrm{NCH}$ was carried out at experimental conditions: $25 \mathrm{mg} / \mathrm{L}$,
$0.3 \mathrm{mg} / \mathrm{L}$ of SCH and $\mathrm{NCH}$ dosage, $\mathrm{pH} 8,50 \mathrm{ml}$ of volume, $30{ }^{\circ} \mathrm{C}$, and the time is varied between 0 and $120 \mathrm{~min}$. To understand the kinetics mechanism, two well-known kinetic models were employed such as pseudo-first-order (PSO) and pseudo-second-order (PSO) model. A detailed description of these models is presented in Table $S 3[2,7$, 34]. The PSO kinetic fitting curves and the results obtained from the nonlinear regression analysis are presented in Fig. 8 and Table 8 , respectively. The data presented in Table 8 suggest that PSO model better explains the kinetic data with high values $R^{2}$ and low values of RSS and ARE. This is possibly attributed due to the formation of a chemical bond or electrostatic attraction between adsorbate and adsorptive sites present on the $\mathrm{SCH}$ and $\mathrm{NCH}$, and maybe chemisorption is the rate-controlling step. Also, the adsorption rate is proportional to the square of a number of unoccupied adsorption sites $[67,68]$.

\subsubsection{Adsorption isotherm}

To estimate the maximum adsorption capacity and to optimise the design of adsorption systems, widely used isotherm models, Langmuir, Freundlich, Temkin and D-R isotherm model, were employed. The details of these models are given in Table S4 [4,69]. The effect of initial dye concentration MB on adsorption capacity of $\mathrm{SCH}$ and $\mathrm{NCH}$ was studied under experimental conditions: $50 \mathrm{ml}$ dye solution, $\mathrm{pH} 8$, temperature $30^{\circ} \mathrm{C}$ and adsorbent dosage of $0.3 \mathrm{~g} / \mathrm{L}$ and $0.2 \mathrm{~g} / \mathrm{L}$ for $\mathrm{SCH}$ and $\mathrm{NCH}$, respectively.
Table 8 Kinetics constants and statistical parameters for $\mathrm{MB}$ adsorption onto $\mathrm{SCH}$ and $\mathrm{NCH}$ adsorbent

\begin{tabular}{|c|c|c|c|c|c|c|}
\hline \multirow[t]{2}{*}{ Adsorbent } & \multirow[t]{2}{*}{ Model } & \multicolumn{2}{|c|}{ Model parameters } & \multicolumn{3}{|c|}{ Statistical parameters } \\
\hline & & & & $\mathrm{R}^{2}$ & RSS & ARE \\
\hline \multirow[t]{4}{*}{$\mathrm{SCH}$} & PFO & $\mathrm{k}_{1}$ & $\mathrm{q}_{\mathrm{e}}$ & & & \\
\hline & & 0.0532 & 35.4344 & 0.9790 & 36.0025 & 7.6827 \\
\hline & PSO & $\mathrm{k}_{2}$ & $\mathrm{q}_{\mathrm{e}}$ & & & \\
\hline & & 0.0016 & 40.7976 & 0.9949 & 7.7663 & 3.3095 \\
\hline \multirow[t]{4}{*}{$\mathrm{NCH}$} & PFO & $\mathrm{k}_{1}$ & $\mathrm{q}_{\mathrm{e}}$ & & & \\
\hline & & 0.0829 & 37.4395 & 0.9820 & 27.7171 & 4.9076 \\
\hline & PSO & $\mathrm{k}_{2}$ & $\mathrm{q}_{\mathrm{e}}$ & & & \\
\hline & & 0.0027 & 41.9192 & 0.9969 & 4.6567 & 2.1680 \\
\hline
\end{tabular}


Table 9 Adsorption isotherm constants and statistical parameters for adsorption of $\mathrm{MB}$ onto $\mathrm{SCH}$ and $\mathrm{NCH}$

\begin{tabular}{|c|c|c|c|c|c|c|}
\hline \multirow[t]{2}{*}{ Adsorbent } & \multirow[t]{2}{*}{ Model } & \multicolumn{2}{|c|}{ Model parameters } & \multicolumn{3}{|c|}{ Statistical parameters } \\
\hline & & & & $\overline{R^{2}}$ & RSS & ARE \\
\hline \multirow[t]{8}{*}{$\mathrm{SCH}$} & Langmuir & $\mathrm{K}_{\mathrm{L}}$ & $\mathrm{q}_{\max }$ & & & \\
\hline & & 0.0791 & 129.43 & 0.9290 & 443.60 & 12.29 \\
\hline & Freundlich & $\mathrm{K}_{\mathrm{f}}$ & $\mathrm{n}$ & & & \\
\hline & & 27.493 & 3.01 & 0.9600 & 182.60 & 5.91 \\
\hline & Temkin & $\mathrm{K}_{\mathrm{T}}$ & $\mathrm{b}_{\mathrm{T}}$ & & & \\
\hline & & 0.042 & 36.44 & 0.9562 & 198.16 & 6.1 \\
\hline & $\mathrm{D}-\mathrm{R}$ & $Q_{D R}$ & $\mathrm{~K}_{\mathrm{DR}}$ & & & \\
\hline & & 112.18 & $2.35 \times 10^{-3}$ & 0.9412 & 202.12 & 9.2 \\
\hline \multirow[t]{8}{*}{$\mathrm{NCH}$} & Langmuir & $\mathrm{K}_{\mathrm{L}}$ & $\mathrm{q}_{\max }$ & & & \\
\hline & & 0.1271 & 199.73 & 0.9213 & 1497.48 & 13.55 \\
\hline & Freundlich & $K_{f}$ & $\mathrm{n}$ & & & \\
\hline & & 52.899 & 3.31 & 0.9871 & 163.58 & 3.23 \\
\hline & Temkin & $\mathrm{K}_{\mathrm{T}}$ & $\mathrm{b}_{\mathrm{T}}$ & & & \\
\hline & & 1.807 & 38.071 & 0.9789 & 283.211 & 4.63 \\
\hline & $\mathrm{D}-\mathrm{R}$ & $\mathrm{Q}_{\mathrm{DR}}$ & $\mathrm{K}_{\mathrm{DR}}$ & & & \\
\hline & & 159.55 & $8.57 \times 10^{-4}$ & 0.7757 & 1555 & 16.12 \\
\hline
\end{tabular}

Table 10 Comparison of adsorption capacities of various $\mathrm{NaOH}-$ treated biomass-based adsorbents for removal of methylene blue

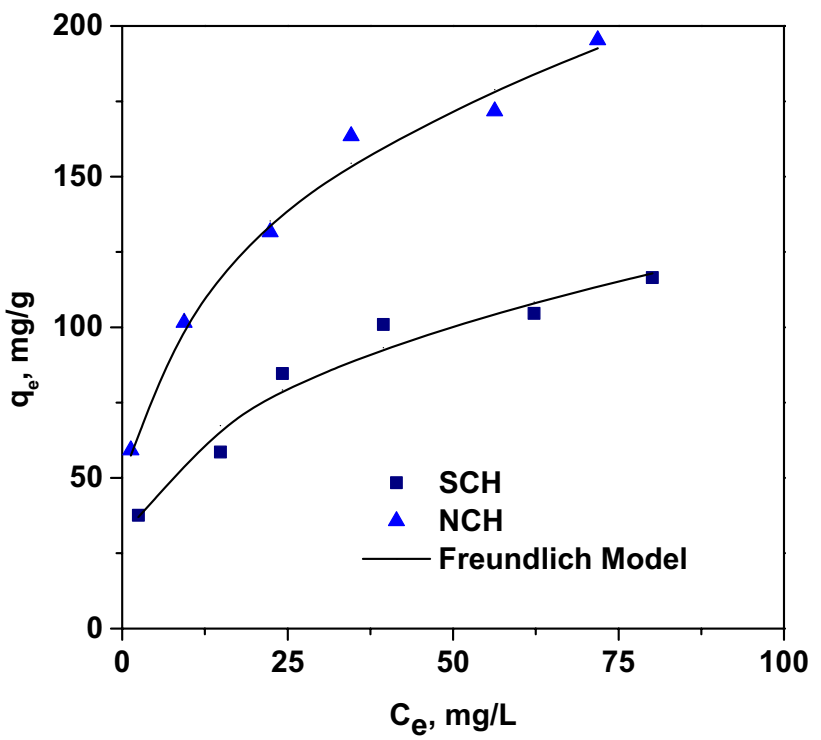

\begin{tabular}{llll}
\hline SI. No. & Biomass & $\begin{array}{l}\mathrm{q}_{\max } \\
(\mathrm{mg} / \mathrm{g})\end{array}$ & References \\
\hline 1 & Foumanat tea waste & 461.00 & {$[33]$} \\
2 & Rice husk & 342.43 & {$[31]$} \\
3 & Cocoa pod husk & 263.90 & {$[71]$} \\
4 & Rejected tea & 242.11 & {$[72]$} \\
5 & Pinecone powder & 142.25 & {$[73]$} \\
6 & Sawdust & 109.80 & {$[74]$} \\
7 & Brazilian ironwood fruits & 125.20 & {$[75]$} \\
8 & Orange tree sawdust & 78.70 & {$[76]$} \\
9 & Coffee husk (NaOH treated) & 199.73 & Present study \\
10 & Coffee husk (autoclaved) & 129.43 & Present study \\
\hline
\end{tabular}

is appropriate to heterogeneous surfaces with different adsorption energies having adsorption sites. The values of $\mathrm{n}$ in the range between 1 and 10 indicate the adsorption of $\mathrm{MB}$ onto $\mathrm{SCH}$ and $\mathrm{NCH}$ is favourable [70]. According to the Langmuir model, the maximum monolayer adsorption capacity was found to be 129.43 and $199.73 \mathrm{mg} / \mathrm{g}$ for SCH and $\mathrm{NCH}$, respectively. The adsorption capacity of $\mathrm{NCH}$ is higher than $\mathrm{SCH}$, and the higher adsorption capacity of $\mathrm{NCH}$ is due to the reduced particle size and rough surfaces developed after $\mathrm{NaOH}$ treatment. The maximum adsorption capacities $\left(\mathrm{q}_{\max }, \mathrm{mg} / \mathrm{g}\right) \mathrm{MB}$ onto various $\mathrm{NaOH}$-treated biomass are presented in Table 10. This is evident that the $\mathrm{NCH}$ has potential in the removal of cationic dyes from the wastewater. ARE compared to other selected models. This indicates that adsorption of $\mathrm{MB}$ on $\mathrm{SCH}$ and $\mathrm{NCH}$ is multilayer and 


\section{Conclusion}

In this study, the eco-friendly and low-cost adsorbent developed based on coffee husk agricultural waste through a physical and chemical treatment was employed for methylene blue removal from synthetic wastewater. Besides reducing the coffee husk waste, the outcomes also provide additional benefits to dye effluent treatment from wastewater. The influence of adsorption process parameters, viz. solution $\mathrm{pH}$, adsorbent dosage and initial dye concentration, was investigated by response surface methodology (RSM). For SCH adsorbent, the optimum conditions obtained were at $\mathrm{pH}$ of 7.637 , initial dye concentration of $37.78 \mathrm{mg} / \mathrm{L}$ and adsorbent dosage of $0.740 \mathrm{~g} / \mathrm{L}$, which yielded MB removal percentage of 93.52. In the case of $\mathrm{NCH}$ adsorbent, the optimum conditions were found to be $\mathrm{pH}$ of 7.914, initial dye concentration of 84.495 and adsorbent dosage of 0.406 , which yielded MB removal of $92.48 \%$. It was found that the equilibrium data regressed very well with Freundlich isotherm model, which demonstrated multilayer adsorption of $\mathrm{MB}$ onto $\mathrm{SCH}$ and $\mathrm{NCH}$. The kinetics of $\mathrm{MB}$ adsorption onto $\mathrm{SCH}$ and $\mathrm{NCH}$ has followed the pseudo-second-order kinetic model. Characterisation of adsorbent using SEM and FTIR revealed that there are significant changes in physicochemical properties of raw and treated coffee husk biomass which plays an important role in the adsorption of $\mathrm{MB}$ onto $\mathrm{SCH}$ and $\mathrm{NCH}$. The overall adsorption results revealed that the $\mathrm{NCH}$ is a feasible and low-cost adsorbent for the removal of $\mathrm{MB}$ dye aqueous solutions.

Acknowledgements The authors would like to thank Management, Ramaiah Institute of Technology and Siddaganga Institute of Technology for providing necessary facilities and support.

\section{Compliance with ethical standards}

Conflict of interest The author(s) declared no conflict of interest.

\section{References}

1. Ahsan MA, Jabbari V, Imam MA, Castro E, Kim H, Curry ML, VallesRosales DJ, Noveron JC (2020) Nanoscale nickel metal organic framework decorated over graphene oxide and carbon nanotubes for water remediation. Sci Total Environ 698:134214. https ://doi.org/10.1016/j.scitotenv.2019.134214

2. Islam MT, Hyder AG, Saenz-Arana R, Hernandez C, Guinto T, Ahsan MA, Alvarado-Tenorio B, Noveron JC (2019) Removal of methylene blue and tetracycline from water using peanut shell derived adsorbent prepared by sulfuric acid reflux. J Environ Chem Eng 7:102816. https://doi.org/10.1016/j.jece.2018.10281 6

3. Ismail M, Khan MI, Khan SB, Khan MA, Akhtar K, Asiri AM (2018) Green synthesis of plant supported $\mathrm{Cu}-\mathrm{Ag}$ and $\mathrm{Cu}-\mathrm{Ni}$ bimetallic nanoparticles in the reduction of nitrophenols and organic dyes for water treatment. J Mol Liq 260:78-91. https://doi. org/10.1016/j.molliq.2018.03.058

4. Ahsan MA, Jabbari V, Islam MT, Kim H, Hernandez-Viezcas JA, Lin Y, Díaz-Moreno CA, Lopez J, Gardea-Torresdey J, Noveron JC (2018) Green synthesis of a highly efficient biosorbent for organic, pharmaceutical, and heavy metal pollutants removal: engineering surface chemistry of polymeric biomass of spent coffee waste. J Water Process Eng 25:309-319. https://doi. org/10.1016/j.jwpe.2018.08.005

5. Murthy TPK, Gowrishankar BS, Chandraprabha MN, HariKrishna $R$ (2020) Solution combustion synthesis of calcium aluminate nanocomposite using coffee husk extract as green fuel and its application in adsorptive amputation of anionic dyes. Mater Res Express 7:035503. https://doi.org/10.1088/2053-1591/ab6b65

6. Krishna Murthy TP, Gowrishankar BS, Chandra Prabha MN, Kruthi M, Hari Krishna R (2019) Studies on batch adsorptive removal of malachite green from synthetic wastewater using acid treated coffee husk equilibrium kinetics and thermodynamic studies. Microchem J. https://doi.org/10.1016/j.microc.2018.12.067

7. Ahsan MA, Katla SK, Islam MT, Hernandez-Viezcas JA, Martinez LM, Díaz-Moreno CA, Lopez J, Singamaneni SR, Banuelos J, Gardea-Torresdey J, Noveron JC (2018) Adsorptive removal of methylene blue, tetracycline and $\mathrm{Cr}(\mathrm{VI})$ from water using sulfonated tea waste. Environ Technol Innov 11:23-40. https://doi. org/10.1016/j.eti.2018.04.003

8. $\mathrm{Kv} \mathrm{B}, \mathrm{Bm} N$, Rs R (2015) Adsorption of $\mathrm{Cr}(\mathrm{VI})$ from aqueous solution onto a mesoporous carbonaceous material prepared from naturally occurring pongamia pinnata seeds. J Environ Anal Toxicol 05:1-7. https://doi.org/10.4172/2161-0525.1000330

9. Murthy KTP, Gowrishankar BS, Krishna RH, Chandraprabha MN, Rao RS (2019) Influence of fuel nature on dye adsorption efficiency of solution combustion derived zinc oxide nanoparticles: a comparative study. Mater Res Express 6:055512. https://doi. org/10.1088/2053-1591/aafe3f

10. Adegoke KA, Bello OS (2015) Dye sequestration using agricultural wastes as adsorbents. Water Resour Ind. 12:8-24. https:// doi.org/10.1016/J.WRI.2015.09.002

11. Singh H, Chauhan G, Jain AK, Sharma SK (2017) Adsorptive potential of agricultural wastes for removal of dyes from aqueous solutions. J Environ Chem Eng 5:122-135. https://doi. org/10.1016/J.JECE.2016.11.030

12. Salleh MAM, Mahmoud DK, Karim WAWA, Idris A (2011) Cationic and anionic dye adsorption by agricultural solid wastes: a comprehensive review. Desalination 280:1-13. https://doi. org/10.1016/J.DESAL.2011.07.019

13. Bharathi KS, Ramesh ST (2013) Removal of dyes using agricultural waste as low-cost adsorbents: a review. Appl Water Sci 3:773-790. https://doi.org/10.1007/s13201-013-0117-y

14. Murthy PS, Madhava Naidu M (2012) Sustainable management of coffee industry by-products and value addition-a review. Resour Conserv Recycl 66(2012):45-58. https://doi. org/10.1016/j.resconrec.2012.06.005

15. Rangabhashiyam S, Anu N, Selvaraju N (2013) Sequestration of dye from textile industry wastewater using agricultural waste products as adsorbents. J Environ Chem Eng 1:629-641. https ://doi.org/10.1016/J.JECE.2013.07.014

16. Bhatnagar A, Hogland W, Marques M, Sillanpää M (2013) An overview of the modification methods of activated carbon for its water treatment applications. Chem Eng J 219:499-511. https ://doi.org/10.1016/j.cej.2012.12.038

17. Feng N, Guo X, Liang S (2009) Adsorption study of copper (II) by chemically modified orange peel. J Hazard Mater 164:12861292. https://doi.org/10.1016/J.JHAZMAT.2008.09.096

18. WanNgah WS, Hanafiah MAKM (2008) Removal of heavy metal ions from wastewater by chemically modified plant wastes as 
adsorbents: a review. Bioresour Technol 99:3935-3948. https:// doi.org/10.1016/J.BIORTECH.2007.06.011

19. Pehlivan E, Altun T, Parlayici Ş (2012) Modified barley straw as a potential biosorbent for removal of copper ions from aqueous solution. Food Chem 135:2229-2234. https://doi.org/10.1016/J. FOODCHEM.2012.07.017

20. Selatnia A, Bakhti MZ, Madani A, Kertous L, Mansouri Y (2004) Biosorption of $\mathrm{Cd} 2+$ from aqueous solution by a $\mathrm{NaOH}$-treated bacterial dead Streptomyces rimosus biomass. Hydrometallurgy 75:11-24. https://doi.org/10.1016/J.HYDROMET.2004.06.005

21. Velazquez-Jimenez LH, Pavlick A, Rangel-Mendez JR (2013) Chemical characterization of raw and treated agave bagasse and its potential as adsorbent of metal cations from water. Ind Crops Prod 43:200-206. https://doi.org/10.1016/J.INDCR OP.2012.06.049

22. Abdolali A, Guo WS, Ngo HH, Chen SS, Nguyen NC, Tung KL (2014) Typical lignocellulosic wastes and by-products for biosorption process in water and wastewater treatment: a critical review. Bioresour Technol 160:57-66. https://doi. org/10.1016/J.BIORTECH.2013.12.037

23. Naeem H, Bhatti HN, Sadaf S, Iqbal M (2017) Uranium remediation using modified Vigna radiata waste biomass. Appl Radiat Isot 123:94-101. https://doi.org/10.1016/J.APRAD ISO.2017.02.027

24. Zafar MN, Parveen A, Nadeem R (2013) A pretreated green biosorbent based on neem leaves biomass for the removal of lead from waste water. Desalin Water Treat 51:4459-4466. https ://doi.org/10.1080/19443994.2012.752765

25. Shroff KA, Vaidya VK (2011) Effect of pre-treatments on biosorption of Ni (II) by dead biomass of Mucor hiemalis. Eng Life Sci 11:588-597. https://doi.org/10.1002/elsc.201000205

26. Daneshvar E, Vazirzadeh A, Niazi A, Sillanpää $M$, Bhatnagar $A$ (2017) A comparative study of methylene blue biosorption using different modified brown, red and green macroalgaeeffect of pretreatment. Chem Eng J 307:435-446. https://doi. org/10.1016/J.CEJ.2016.08.093

27. Selvakumar R, Kavitha S, Sathishkumar M, Jayavignesh V, Swaminathan K (2010) Liquid Phase Separation of $A s(V)$ from aqueous solution using pretreated Paecilomyces variotii biomass. Sep Sci Technol 45:776-785. https://doi.org/10.1080/014963909035631 08

28. Binupriya AR, Sathishkumar M, Swaminathan K, Kuz CS, Yun SE (2008) comparative studies on removal of congo red by native and modified mycelial pellets of trametes versicolor in various reactor modes. Bioresour Technol 99:1080-1088. https://doi. org/10.1016/J.BIORTECH.2007.02.022

29. Rangabhashiyam S, Balasubramanian P (2018) Performance of novel biosorbents prepared using native and $\mathrm{NaOH}$ treated Peltophorum pterocarpum fruit shells for the removal of malachite green. Bioresour Technol Rep 3:75-81. https://doi.org/10.1016/J. BITEB.2018.06.004

30. Chakraborty S, Chowdhury S, Das Saha P (2011) Adsorption of crystal violet from aqueous solution onto $\mathrm{NaOH}$-modified rice husk. Carbohydr Polym 86:1533-1541. https://doi. org/10.1016/J.CARBPOL.2011.06.058

31. Ashrafi SD, Kamani H, Mahvi AH (2016) The optimization study of direct red 81 and methylene blue adsorption on $\mathrm{NaOH}$ modified rice husk. Desalin Water Treat 57:738-746. https:// doi.org/10.1080/19443994.2014.979329

32. Chowdhury S, Mishra R, Saha P, Kushwaha P (2011) Adsorption thermodynamics, kinetics and isosteric heat of adsorption of malachite green onto chemically modified rice husk. Desalination 265:159-168. https://doi.org/10.1016/j.desal.2010.07.047

33. Ebrahimian Pirbazari A, Saberikhah E, Badrouh M, Emami MS (2014) Alkali treated foumanat tea waste as an efficient adsorbent for methylene blue adsorption from aqueous solution. Water Resour Ind 6:64-80. https://doi.org/10.1016/J. WRI.2014.07.003

34. Murthy TPK, Gowrishankar BS, Chandra Prabha MN, Kruthi M, Hari Krishna R (2019) Studies on batch adsorptive removal of malachite green from synthetic wastewater using acid treated coffee husk equilibrium, kinetics and thermodynamic studies. Microchem J 146:192-201. https://doi.org/10.1016/J.MICRO C.2018.12.067

35. Mondal NK, Samanta A, Dutta S, Chattoraj S (2017) Optimization of $\mathrm{Cr}(\mathrm{VI})$ biosorption onto aspergillus niger using 3-level Box-Behnken design: equilibrium, kinetic, thermodynamic and regeneration studies. J Genet Eng Biotechnol 15:151-160. https://doi.org/10.1016/J.JGEB.2017.01.006

36. Abolhasani S, Ahmadpour A, Rohani Bastami T, Yaqubzadeh A (2019) Facile synthesis of mesoporous carbon aerogel for the removal of ibuprofen from aqueous solution by central composite experimental design (CCD). J Mol Liq 281:261-268. https://doi.org/10.1016/J.MOLLIQ.2019.02.084

37. Zhang B, Han X, Gu P, Fang S, Bai J (2017) Response surface methodology approach for optimization of ciprofloxacin adsorption using activated carbon derived from the residue of desilicated rice husk. J Mol Liq 238:316-325. https://doi. org/10.1016/J.MOLLIQ.2017.04.022

38. Mahmood T, Ali R, Naeem A, Hamayun M, Aslam M (2017) Potential of used Camellia sinensis leaves as precursor for activated carbon preparation by chemical activation with $\mathrm{H} 3 \mathrm{PO} 4$; optimization using response surface methodology. Process Saf Environ Prot 109:548-563. https://doi.org/10.1016/J. PSEP.2017.04.024

39. Pezoti Junior O, Cazetta AL, Gomes RC, Barizão ÉO, Souza IPAF, Martins AC, Asefa T, Almeida VC (2014) Synthesis of $\mathrm{ZnCl}$-activated carbon from macadamia nut endocarp (Macadamia integrifolia) by microwave-assisted pyrolysis: optimization using RSM and methylene blue adsorption. J Anal Appl Pyrolysis 105:166-176. https://doi.org/10.1016/J. JAAP.2013.10.015

40. Hadi S, Al-Mashhadani M, Eisa M (2019) Optimization of dye adsorption process for Albizia lebbeck pod as a biomass using central composite rotatable design model. Chem. Ind. Chem. Eng. Q. 25:39-46. https://doi.org/10.2298/CICEQ180210021H

41. Ahsan MA, Jabbari V, Islam MT, Turley RS, Dominguez N, Kim H, Castro E, Hernandez-Viezcas JA, Curry ML, Lopez J, GardeaTorresdey JL, Noveron JC (2019) Sustainable synthesis and remarkable adsorption capacity of MOF/graphene oxide and MOF/CNT based hybrid nanocomposites for the removal of bisphenol a from water. Sci Total Environ 673:306-317. https://doi. org/10.1016/j.scitotenv.2019.03.219

42. Fathy NA, El-Shafey OI, Khalil LB (2013) Effectiveness of alkaliacid treatment in enhancement the adsorption capacity for rice straw: the removal of methylene blue dye. ISRN Phys Chem 2013:15. https://doi.org/10.1155/2013/208087

43. Guo J-Z, Li B, Liu L, Lv K (2014) Removal of methylene blue from aqueous solutions by chemically modified bamboo. Chemosphere 111:225-231. https://doi.org/10.1016/J.CHEMOSPHER E.2014.03.118

44. G. Cruz, Physicochemical Properties of Brazilian Biomasses: Potential Applications As Renewable Energy Physicochemical Properties of Brazilian Biomasses :, in: 22nd Int. Congr. Mech. Eng., 2013. https://doi.org/10.13140/2.1.4761.2485

45. Feng $Y$, Yang F, Wang Y, Ma L, Wu Y, Kerr PG, Yang L (2011) Basic dye adsorption onto an agro-based waste material-sesame hull (Sesamum indicum L). Bioresour Technol 102:10280-10285. https://doi.org/10.1016/J.BIORTECH.2011.08.090

46. Veiga TRLA, Lima JT, Dessimoni ALDA, Pego MFF, Soares JR, Trugilho PF (2017) Different plant biomass characterizations 
for biochar production. CERNE 23:529-536. https://doi. org/10.1590/01047760201723042373

47. Alhogbi BG, Al-Enazi ZF (2018) Retention Profile of Zn $2+$ and $\mathrm{Ni} 2+$ ions from wastewater onto coffee husk: kinetics and thermodynamic Study. J. Encapsulation Adsorpt. Sci. 8:1-17. https ://doi.org/10.4236/jeas.2018.81001

48. Gebresemati M, Gabbiye N, Sahu O (2017) Sorption of cyanide from aqueous medium by coffee husk: response surface methodology. J Appl Res Technol 15:27-35. https://doi.org/10.1016/J. JART.2016.11.002

49. Huang $R$, He L, Zhang $T$, Li D, Tang $P$, Zhao Y, Feng Y, Huang $R, H e$ L, Zhang T, Li D, Tang P, Zhao Y, Feng Y (2018) Fabrication and adsorption behavior of magnesium silicate hydrate nanoparticles towards methylene blue. Nanomaterials 8:271. https://doi. org/10.3390/nano8050271

50. Kumpan N, Poonsawat T, Chaicharoenwimolkul L, Pornsuwan S, Somsook E (2017) Ferrocenated nanocatalysts derived from the decomposition of ferrocenium in basic solution and their aerobic activities for the rapid decolorization of methylene blue and the facile oxidation of phenylboronic acid. RSC Adv 7:5759-5763. https://doi.org/10.1039/C6RA25515A

51. Zhu G, Xing X, Wang J, Zhang X (2017) Effect of acid and hydrothermal treatments on the dye adsorption properties of biomass-derived activated carbon. J Mater Sci 52:7664-7676. https ://doi.org/10.1007/s10853-017-1055-0

52. Kocaman S, Karaman M, Gursoy M, Ahmetli G (2017) Chemical and plasma surface modification of lignocellulose coconut waste for the preparation of advanced biobased composite materials. Carbohydr Polym 159:48-57. https://doi. org/10.1016/J.CARBPOL.2016.12.016

53. Kafshgari LA, Ghorbani M, Azizi A, Agarwal S, Gupta VK (2017) Modeling and optimization of direct red 16 adsorption from aqueous solutions using nanocomposite of MnFe2O4/MWCNTs: RSM-CCRD model. J Mol Liq 233:370-377. https://doi. org/10.1016/J.MOLLIQ.2017.03.047

54. Dashtian K, Zare-Dorabei R (2017) Synthesis and characterization of functionalized mesoprous SBA-15 decorated with $\mathrm{Fe} 3 \mathrm{O} 4$ nanoparticles for removal of $\mathrm{Ce}(\mathrm{III})$ ions from aqueous solution: ICP-OES detection and central composite design optimization. J Colloid Interf Sci 494:114-123. https://doi.org/10.1016/J. JCIS.2017.01.072

55. Ghasemi E, Heydari A, Sillanpää M (2019) Central composite design for optimization of removal of trace amounts of toxic heavy metal ions from aqueous solution using magnetic $\mathrm{Fe} 3 \mathrm{O} 4$ functionalized by guanidine acetic acid as an efficient nanoadsorbent. Microchem J 147:133-141. https://doi.org/10.1016/J. MICROC.2019.02.056

56. Mortazavian S, Saber A, James DE (2019) Optimization of photocatalytic degradation of acid blue 113 and acid red 88 textile dyes in a UV-C/TiO2 suspension system: application of response surface methodology (RSM). Catalysts 9:360. https:// doi.org/10.3390/catal9040360

57. Shojaei S, Shojaei S (2018) Optimization of process variables by the application of response surface methodology for dye removal using nanoscale zero-valent iron. Int J Environ Sci Technol. https://doi.org/10.1007/s13762-018-1866-9

58. Nekouei Marnani N, Shahbazi A (2019) A novel environmentalfriendly nanobiocomposite synthesis by EDTA and chitosan functionalized magnetic graphene oxide for high removal of Rhodamine B: adsorption mechanism and separation property. Chemosphere 218:715-725. https://doi.org/10.1016/J. CHEMOSPHERE.2018.11.109

59. Sahu UK, Sahu MK, Mahapatra SS, Patel RK (2017) Removal of $\mathrm{As}$ (III) from aqueous solution using Fe3O4 Nanoparticles: process modeling and optimization using statistical design.
Water Air Soil Pollut 228:45. https://doi.org/10.1007/s1127 0-016-3224-1

60. Shojaei S, Shojaei S, Pirkamali M (2019) Application of BoxBehnken design approach for removal of acid black 26 from aqueous solution using zeolite: modeling, optimization, and study of interactive variables. Water Conserv Sci Eng 4:13-19. https://doi.org/10.1007/s41101-019-00064-7

61. Abdulhameed AS, Mohammad A-T, Jawad AH (2019) Application of response surface methodology for enhanced synthesis of chitosan tripolyphosphate/TiO2 nanocomposite and adsorption of reactive orange 16 dye. J Clean Prod 232:43-56. https://doi.org/10.1016/J.JCLEPRO.2019.05.291

62. Design Expert V11, Tutorials on response surface methodology, state-ease. (2018). https://www.statease.com/docs/v11/ tutorials/multifactor-rsm/ (Accessed July 17, 2019)

63. Zhong L, Tang A, Yan P, Wang J, Wang Q, Wen X, Cui Y (2019) Palygorskite-template amorphous carbon nanotubes as a superior adsorbent for removal of dyes from aqueous solutions. J Colloid Interf Sci 537:450-457. https://doi. org/10.1016/J.JCIS.2018.11.016

64. Sharma A, Siddiqui ZM, Dhar S, Mehta P, Pathania D (2019) Adsorptive removal of congo red dye (CR) from aqueous solution by Cornulaca monacantha stem and biomass-based activated carbon: isotherm, kinetics and thermodynamics. Sep Sci Technol 54:916-929. https://doi.org/10.1080/01496 395.2018.1524908

65. Behl K, Sinha S, Sharma M, Singh R, Joshi M, Bhatnagar A, Nigam S (2019) One-time cultivation of Chlorella pyrenoidosa in aqueous dye solution supplemented with biochar for microalgal growth, dye decolorization and lipid production. Chem Eng J 364:552-561. https://doi.org/10.1016/J. CEJ.2019.01.180

66. Tezcan Un U, Ates F (2019) Low-cost adsorbent prepared from poplar sawdust for removal of disperse orange 30 dye from aqueous solutions. Int J Environ Sci Technol 16(2019):899-908. https://doi.org/10.1007/s13762-018-1716-9

67. Razmi FA, Ngadi N, Wong S, Inuwa IM, Opotu LA (2019) Kinetics, thermodynamics, isotherm and regeneration analysis of chitosan modified pandan adsorbent. J Clean Prod 231:98-109. https://doi.org/10.1016/J.JCLEPRO.2019.05.228

68. Oyekanmi AA, Ahmad A, Hossain K, Rafatullah M (2019) Adsorption of Rhodamine $B$ dye from aqueous solution onto acid treated banana peel: response surface methodology, kinetics and isotherm studies. PLoS ONE 14:e0216878. https://doi. org/10.1371/journal.pone.0216878

69. Ahsan MA, Islam MT, Imam MA, Hyder AHMG, Jabbari V, Dominguez N, Noveron JC (2018) Biosorption of bisphenol A and sulfamethoxazole from water using sulfonated coffee waste: isotherm, kinetic and thermodynamic studies. J. Environ Chem Eng 6:6602-6611. https://doi.org/10.1016/j.jece.2018.10.004

70. Jiryaei Sharahi F, Shahbazi A (2017) Melamine-based dendrimer amine-modified magnetic nanoparticles as an efficient $\mathrm{Pb}$ (II) adsorbent for wastewater treatment: adsorption optimization by response surface methodology. Chemosphere 189:291-300. https://doi.org/10.1016/J.CHEMOSPHERE.2017.09.050

71. ling Pua F, Sajab MS, Chia CH, Zakaria S, Rahman IA, Salit MS (2013) Alkaline-treated cocoa pod husk as adsorbent for removing methylene blue from aqueous solutions. J Environ Chem Eng 1:460-465. https://doi.org/10.1016/J.JECE.2013.06.012

72. Nasuha N, Hameed BH (2011) Adsorption of methylene blue from aqueous solution onto $\mathrm{NaOH}$-modified rejected tea. Chem Eng J 166:783-786. https://doi.org/10.1016/J.CEJ.2010.11.012

73. Yagub MT, Sen TK, Ang M (2014) Removal of cationic dye methylene blue (MB) from aqueous solution by ground raw and base modified pine cone powder. Environ Earth Sci 71:1507-1519. https://doi.org/10.1007/s12665-013-2555-0 
74. Azzaz AA, Jellali S, Souissi R, Ergaieg K, Bousselmi L (2017) Alkaline-treated sawdust as an effective material for cationic dye removal from textile effluents under dynamic conditions: breakthrough curve prediction and mechanism exploration. Environ Sci Pollut Res 24:18240-18256. https://doi.org/10.1007/s1135 6-017-9388-4

75. Carvalho LB, Chagas PMB, Pinto LMA (2018) Caesalpinia ferrea Fruits as a Biosorbent for the Removal of Methylene Blue Dye from an Aqueous Medium. Water Air Soil Pollut 229:297. https ://doi.org/10.1007/s11270-018-3952-5

76. Azzaz AA, Jellali S, Akrout H, Assadi AA, Bousselmi L (2017) Optimization of a cationic dye removal by a chemically modified agriculture by-product using response surface methodology: biomasses characterization and adsorption properties. Environ Sci Pollut Res 24:9831-9846. https://doi.org/10.1007/s1135 6-016-7698-6

Publisher's Note Springer Nature remains neutral with regard to jurisdictional claims in published maps and institutional affiliations. 